RESEARCH ARTICLE

\title{
The biogeography and ecology of Sri Lankan mammals point to conservation priorities
}

\author{
Wolfgang P. J. Dittus ${ }^{1,2,3, *}$ \\ ${ }^{1}$ National Institute of Fundamental Studies, Kandy 2000, Sri Lanka. \\ ${ }^{2}$ Association for the Conservation of Primate Diversity, Sri Lanka \\ ${ }^{3}$ Conservation Ecology Center, Smithsonian Conservation Biology Institute, Washington, DC 20013, USA.
}

Received: 17/12/2016; Accepted: 15/10/2017

\begin{abstract}
All mammals originated on the supercontinent of Pangaea in the Mesozoic era during the "Age of Reptiles." However, the crown ancestors of contemporary mammals did not flourish until major environmental and biotic changes had occurred. An asteroid collided with earth at the end of the Cretaceous Period (the K-Pg boundary event) wiping out nonflying dinosaurs and primitive mammals. It was followed by large-scale volcanism, a spike in atmospheric oxygen and the proliferation of flowering plants. New niches became available for the ancestors of today's mammals to fill. Evidence suggesting whether the ancestors of the Sri Lankan and Indian mammals originated on the tectonically marooned Indian plate before crashing into Asia or on the Laurasian supercontinent is inconclusive. Modern Sri Lankan mammals show their greatest affinity with those of southern India, and were more diverse in the Pleistocene when rhinoceros, hippopotamus, wild dogs, gaur and lions enriched the island's landscapes. Native Sri Lankan land-based mammals are diversified into about 108 unique taxa (among 91 species and 53 genera), differentiated as phenotypic adaptations to sharply contrasting environments among seven major phyto-climatic zones. Endemic subspecies are distributed fairly equally across different phyto-climatic zones ( $\mathrm{n}=24$ to $29)$, except in the highlands where they are fewer $(n=14)$ having evolved rapidly to species and genera among the insectivores and rodents whose reproductive rates are high. Conversely, greater numbers of endemic species $(n=13)$ and genera $(n=3)$ occur in the highlands than in the other zones (2-6 endemic species, no endemic genera). The prevalence of endemism is inversely related to body size or vagility. This suggests a greater probability of genetic exchange among distant populations of large bodied mobile mammals within Sri Lanka, as well as with Indian fauna during periods of land bridges in the Pleistocene. Most (8 of 13) endangered and critically endangered endemic mammals occur in the wet montane regions that offer the least Protected Areas (PAs). More than $85 \%$ of PAs occur in the extensive dry zone about half of which is not suited for water dependent mammals whose distributions are restricted to alluvial forests (less than $1 \%$ of PAs). Historically, the national cost of conservation has been low and therefore politically palatable. Current conservation urgently requires a major change in management policy combined with realistic investment to prevent extinctions of many endemic mammals and other unique Sri Lankan biota.
\end{abstract}

Keywords: endemism, evolutionary stable unit, mammal subspecies, habitat quality, ecological niche, mammalian evolution.

\section{INTRODUCTION}

Chance events in the geological history of the earth have placed Sri Lanka in a globally unique position with respect to biodiversity. Apical flora and fauna reside in Sri Lanka, especially in the highlands. They are the products of at least 200 million year biological evolution and adaptation to the shifting of continental plates, massive volcanic eruptions and periods of glaciation. This extraordinary gift of nature to Sri Lanka is not widely appreciated and is under threat of permanent loss. The study of biogeography opens our eyes to the nation's priceless biological heritage and underscores the urgency of safeguarding it.

The aims of this report are: firstly, to reiterate the importance of focusing not merely on the species, but especially on the subspecies of Sri Lankan mammals for conserving their diversity (Dittus, 2013); secondly, to relate the taxonomic differentiation of mammals to their biogeography, through geological time (Figure 1) and to the various contemporary phyto-climatic environments of Sri Lanka; and finally, to reflect on the status and challenges of conserving mammalian biodiversity in relation to ecology and supporting habitats.

Why is biogeography of interest? It is the study of the distribution of species and ecosystems in geographic space and through geological time. Organisms and biological communities often vary in a regular fashion along geographic gradients of latitude, elevation, isolation and habitat area, leaving clues to pivotal turning points in evolutionary history. The phenomenon was first brought to our attention formally in the $19^{\text {th }}$ century by the Prussian naturalist Alexander von Humboldt who documented it among plants (phytobiography) (Humboldt, 1805); Alfred Wallace described it later among animals (zoogeography) (Wallace, 1876); and it was pivotal empirical support for clarifying the process of natural selection by Charles Darwin (Darwin, 1859), and continental drift (known today as plate tectonics) by Alfred Wegener (Wegener, 1915). The seminal work by MacArthur and Wilson (1967) established the modern quantitative study of biogeography and described many of the processes involved.

Knowing the phylogeny of organisms and why they are found in their present locations is important for making informed conservation decisions. So we need an appreciation of the evolutionary process and ecological adaptation. The evolution of new forms of life rests on 


\begin{tabular}{|c|c|c|c|c|}
\hline Era & \multicolumn{2}{|c|}{ Period } & Epoch & $\begin{array}{c}\text { Time Began } \\
\text { (Million Years) }\end{array}$ \\
\hline \multirow{7}{*}{ Cenozoic } & \multirow{2}{*}{\multicolumn{2}{|c|}{ Quaternary }} & Holocene & 0.01 \\
\hline & & & \begin{tabular}{|l} 
Pleistocene \\
\end{tabular} & 1.8 \\
\hline & \multirow{5}{*}{ Tertiary } & \multirow{2}{*}{ Neogene } & Pliocene & 5.3 \\
\hline & & & Miocene & 23.0 \\
\hline & & \multirow{3}{*}{ Paleogene } & Oligocene & 33.9 \\
\hline & & & Eocene & 55.8 \\
\hline & & & Paleocene & 65.5 \\
\hline \multirow{3}{*}{ Mesozoic } & \multicolumn{2}{|c|}{ Cretaceous } & & 146 \\
\hline & \multicolumn{2}{|c|}{ Jurassic } & & 200 \\
\hline & \multicolumn{2}{|c|}{ Triassic } & & 251 \\
\hline \multirow{7}{*}{ Paleozoic } & \multicolumn{2}{|c|}{ Permian } & & 299 \\
\hline & \multirow{2}{*}{ Carboniferous } & Pennsylvanian & & 318 \\
\hline & & Mississippian & & 359 \\
\hline & \multicolumn{2}{|c|}{ Devonian } & & 416 \\
\hline & \multicolumn{2}{|c|}{ Silurian } & & 444 \\
\hline & \multicolumn{2}{|c|}{ Ordovician } & & 488 \\
\hline & \multicolumn{2}{|c|}{ Cambrian } & & 542 \\
\hline
\end{tabular}

Figure 1: Geological time table.

individual and population differences in phenotypic adaptations to local environments. If the environment changes, so do the adaptations to it.

Volcanic activity and glacial bursts create an instant impact on the environment. Change in environmental properties can also be gradual over long periods of time, such as plate tectonics, continental glaciation, and climate change. The affected habitats vary in extent and location, and it may involve local or mass extinctions of life. Within a species, genetic and phenotypic changes arising in one population may spread to neighboring ones, even across geographic barriers, through dispersal. Alternatively, population differences may develop through vicariance, when a formerly widespread population is subdivided through geographic barriers, such as mountains or oceans that prevent genetic exchange. Phenotypic adaptation to the environment, therefore, is a dynamic process that has given rise to a great diversity of living and extinct organisms differing in their global distribution over contrasting landscapes. MacArthur and Wilson (1967) provided a theoretical and practical framework for analyzing biogeographical phenomena, and Heaney (1986) applied it to the mammals of Southeast Asia.

Recent advances in molecular genetics adds an important new dimension to this body of knowledge (Riddle et al., 2008). Insofar as evolution involves alterations in the frequency of genes responsible for phenotypic adaptation, an examination of genetic profiles of taxonomic relationships is useful in defining the development of phylogenetic relationships on a geological time scale and for the construction of phylogenetic species trees (Murphy et al., 2001a, b; Sims et al., 2009). In the context of Sri Lankan mammals, for example, molecular studies have clarified our understanding of the genetic population structure and/or taxonomic relationships in macaque monkeys (Shotake et al., 1971; Hoelzer et al., 1994), leopards (Miththapala et al., 1991, 1996), elephants (Fernando et al., 2000) and shrews (Meegaskumbara et al., 2007, 2008). When molecular data are combined with information about ecology, or niche requirements, it provides a greater resolution not only of a taxon's past, but also of its potential for future survival. Knowing the limits of a taxon's adaptation in terms of ecology and geographical distribution across varying environments is clearly useful information for conservation planning.

Reflecting on the origins of Sri Lankan mammals gives us a deeper appreciation of their unique nature and place in relation to other mammals in the world, including humans, and to other faunal groups of Sri Lanka and the region.

\section{THE ORIGIN OF SRI LANKAN MAMMALS}

\section{The break-up of Pangea}

The geological history of Sri Lanka is closely tied to that of India; both were linked at the heart of the ancient supercontinent of Pangea during the Mesozoic when Sri Lanka was geologically connected to Madagascar, Africa, southern India and Antarctica (Dissanayake and Chandrajith, 1999). The first mammal-like creatures evolved under the ecological dominance of the dinosaurs on this supercontinent. These early mammals, known as morganucodontids, were no larger than the size of a cat and represented the ancestors of both marsupial and placental mammals.

Under the force of plate tectonics Pangaea began to break up during the Jurassic period, about 150 to 220 Million years ago (Mya) into two major supercontinents pulling apart: Laurasia to the north (including North America, Europe and Holarctic Asia) and Gondwana to the south (the southern continents) (Figure 2). At this time also, the first marsupial mammals evolved in Laurasia and spread into some parts of southern Gondwana by way of still existing connections as the two supercontinents pulled apart. While Laurasia stayed more or less intact as a supercontinent in the north, about 180 Mya Gondwana broke into a jigsaw puzzle of continents and isles in the Southern Hemisphere. One of those was a giant island forming what we now call India (including Sri Lanka). The other fragments of Gondwana comprised the two huge land masses; one including South America, Africa and Madagascar and the other Australia and Antarctica (Figure 2).

Just prior to the split of Gondwana, fossil evidence from 125 Mya points to a substantial fauna of the first placental 


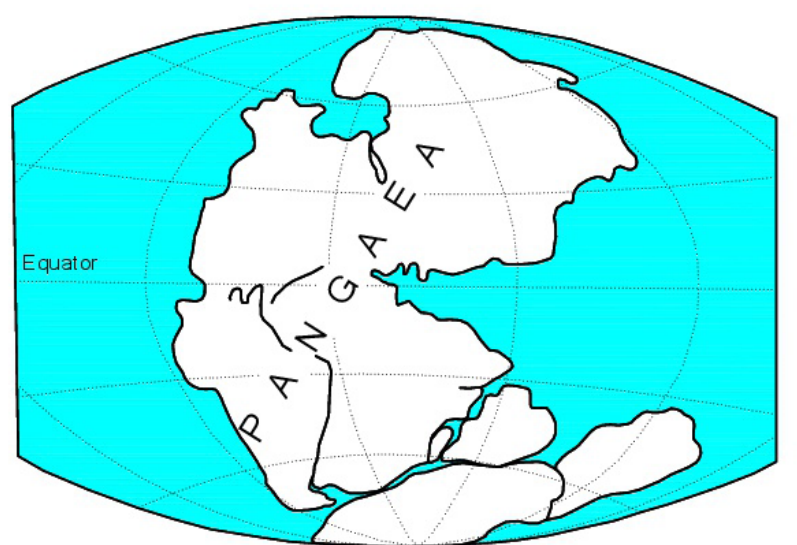

PERMIAN

250 million years ago

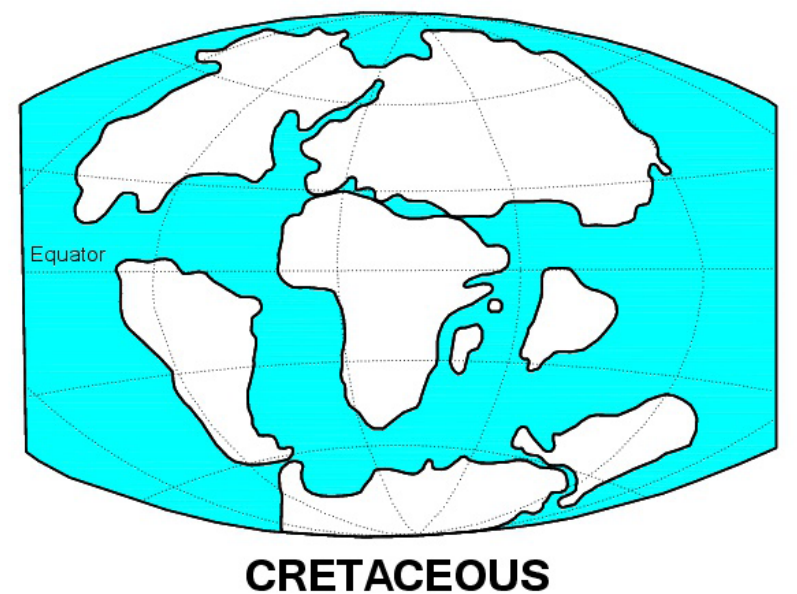

65 million years ago

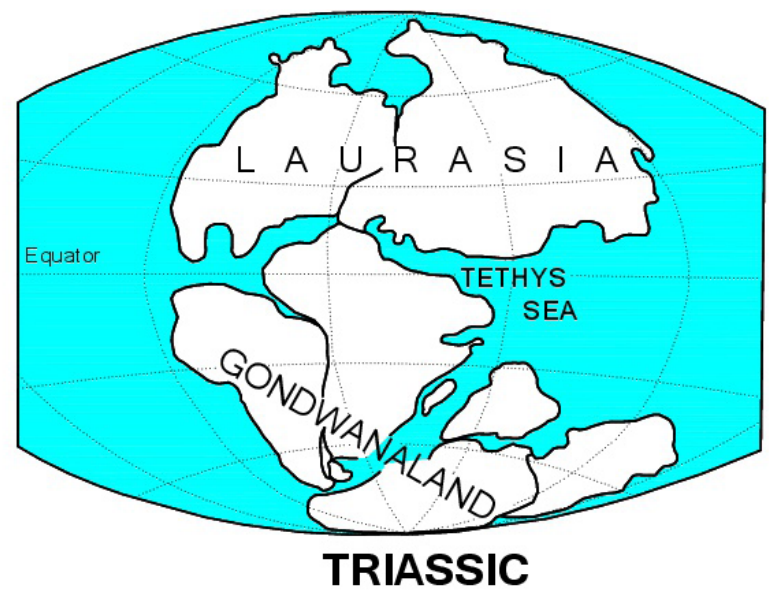

200 million years ago

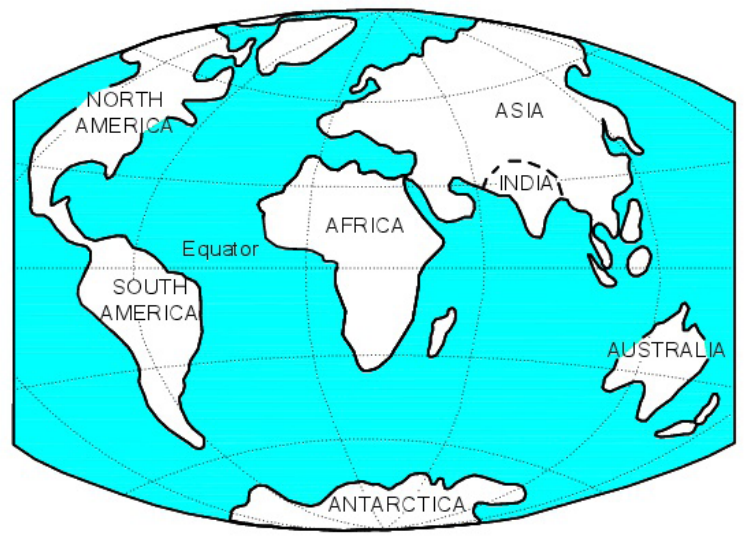

PRESENT DAY

Figure 2: The geological history of India and Sri Lanka in relation to plate tectonics. Sri Lanka has always been connected to the Indian subcontinent that was part of Pangaea during the Permian period (250 to 300 Mya). Pangaea split apart at the end of the Triassic (200 Mya) into two supercontinents: Laurasia to the north and Gondwana drifting southward. Gondwana itself broke apart about 180 Mya ago into progressively more separated landmasses that we know today as South America, Africa, Antarctica, Australia, the Arabian Peninsula and India. For about 90 My India drifted rapidly northward as an isolated island in the Thethys Sea and crashed into Laurasia about 35 to 55 Mya to take up its present position. Fluctuating sea levels have repeatedly submerged or emerged the land bridge connecting India and Sri Lanka at the shallow Palk Strait during the Pleistocene (Modified from The Future Mapping Company, UK).

mammals (Eutheria) in central Laurasia coexisting with dinosaurs (Ji et al., 2002). About 65.5 Mya, at the end of the Cretaceous period, an asteroid plummeted into our planet at what is now Chicxulub, Mexico. The catastrophe set off major climatic and ecological upheavals that spelled the end for the age of dinosaurs, as well as for some early mammals (Alvarez et al., 1980; Schulte et al., 2010). The globally ubiquitous geological strata marking this event are referred to as the Cretaceous-Paleogene (K-Pg) boundary. The extinction of non-flying dinosaurs after the K-Pg boundary opened ecological niches; the remaining early mammals could exploit previously inaccessible resources. Within a few million years of the impact the fossil record shows an explosion in mammalifan diversity in Laurasia (Halliday et al., 2015). This proliferation by-passed the ancestral placentals and instead involved mostly an ancient mammal lineage, the rodent-like multituberculates that themselves became extinct, leaving no descendants to the present (Bininda-Emonds et al., 2007). The extinctions near the K-Pg boundary, particularly in India and Sri Lanka, may have been exacerbated by major basalt flow volcanism on the Deccan at about 65 Mya shortly after the asteroid struck the earth (Bajpai, 2009).

The integration of molecular data, the fossil record, and theoretical models can give probing but sometimes conflicting views of the evolutionary past. For example, analysis of a comprehensive data set relating to mammalian origins suggested that most placentals originated after the $\mathrm{K}-\mathrm{Pg}$ boundary in the early Cenozoic (O'Leary et al., 2013). However, a reanalysis of the same data set along with new evidence placed the placental mammal origins substantially before the K-Pg boundary (Tarver et al., 2016), in keeping with earlier estimates (Eizirik et al., 2001; Ji et al., 2002). These Eocene placentals, with pre-K-Pg roots, are the ancestors of modern mammalian groups (perissodactyls, artiodactyls, primates, rodents, and 
carnivores) we know today (Bowen et al., 2002; Solé and Smith, 2013; Halliday and Goswami, 2016).

\section{The "out of Asia" hypothesis for the origin of Indian and Sri Lankan mammals}

India was marooned as an island from Gondwana in the Jurassic (150-200 Mya), before flowering plants were common and marsupials or placental mammals had evolved. Therefore, the early biota of India would have been like that of the rest of Gondwana at that time. It would have had dinosaurs as well as early types of Mesozoic mammals. Of a more primitive evolutionary grade than the marsupials or placentals, these primitive types (Gondwanatheria) were widespread in the Mesozoic world (Krause et al., 1997; Cox and Moore, 2010). For many years scientists had no fossil evidence of ancestors of any of the large mammals we now associate with India - elephants, tigers, lions, primates. This created a great scientific mystery: How did India get its mammals?

According to the leading "out of Asia" hypothesis Laurasia was the site of evolution of the placental mammals. These placentals dispersed southward, outcompeting and replacing the marsupials on still connected land masses (excluding Australia) (Bowen et al., 2002). Furthermore, the theory posits that after tectonic forces caused India to crash into Laurasia between 55 to $35 \mathrm{Mya}$, or possibly later (Aitchinson et al., 2007), the ancestors of these mammals moved into India from Africa (again reconnected to Laurasia), Southeast Asia and northern Asia. These immigrant mammals spread out across the Indian subcontinent, occupying climates to which they were best adapted and at times diversifying into new species (Bowen et al., 2002). This hypothesis is strongly supported by the absence of marsupial or placental fossils on the Indian subcontinent prior to its collision with Laurasia 55 to 35 Mya.

One of the most enigmatic biogeographical puzzles relating to this hypothesis is posed by the highly disjunct distribution of living strepsirrhine primates; the Lorisidae (loris) and Galagidae (bushbabies and pottos). The crown strepsirrhine lineage has African roots dating back to the late Eocene (about $40 \mathrm{Mya}$ ), and split into one galagine and two lorisine lineages shortly thereafter (about 38 Mya) (Seiffert et al., 2003; Pozzi et al., 2015). One lorisine lineage remained in tropical Africa with the galagines, the other migrated north out of Africa and into Asia by way of temporary Afro-Arabian land bridges (Masters et al., 2005). Once in Asia, this lineage split into the primorida of genera Nycticebus, now found in Southeast Asia, and Loris, now found in India and Sri Lanka (Yoder, 1997). This evidence of a past dispersal event involving thousands of kilometers is surprising in the light of the limited vagility of lorises as well as the fact that their much more mobile sister taxon, the Galagidae, does not occur outside sub-Saharan Africa (Masters et al., 2005).

\section{The "out of India" hypothesis}

More recent evidence challenges the "out of Asia" view. Firstly, phylogenetic reconstructions based on molecular genetics and taking into account the first appearance of placental fossils in Laurasia 125 Mya, suggest that the oldest stem eutherian placental mammals originated earlier from Gondwana rather than Laurasia (Woodburne and Springer, 2003; Rose and Archibald, 2005). Secondly, fossils with European (Laurasian) kinship and representing the precursors of modern perissodactyls, primates and rodents were found in north-western India mixed with typical Gondwanan fauna, from a period (54 Mya) that predated the collision of India with Asia (Rose et al., 2014). This has given rise to suggestions of occasional Laurasian land connections (chains of island stepping-stones) to India as the island plate traversed the ocean towards northern Asia (Masters et al., 2006; Ali et al., 2008), particularly during ocean low levels in the Oligocene (Schlanger and Silva, 1986; Miller et al., 2008).

Alternatively, these modern forms developed from early Pangaean mammals on the Indian plate itself during its long period of isolation (65 to $90 \mathrm{My}$ ) from the rest of Gondwana and Laurasia (Figure 2). When India collided with Laurasia, these modern descendants of Gondwanan origin spilled into Asia and populated the mammalian fauna in keeping with the "out of India" hypothesis (Murphy et al., 2001a; Solé and Smith, 2013; Rose et al., 2014). Until the true origin of the European type mammals dug up in India is resolved, and the timing between phylogenetic divergences in relation to geological events (Aitchison et al., 2007) are substantiated, all contending hypotheses are on hold (Bajpai, 2009; O'Leary et al., 2013; Tarver et al., 2016).

The "out of India" hypothesis, though equivocal for the origin of Cenozoic Indian mammals is consistent with the origin of relics among plants, freshwater fish, crustaceans, amphibians, reptiles and some insects and birds for which the ancestors of these biota were present in Gondwana before India fragmented off from Pangaea in the Jurassic (Karanth, 2006). Datta-Roy and Karanth (2009) outline different scenarios for the origin of non-mammalian Indian biota.

\section{The Tertiary period globally and in Sri Lanka}

The Tertiary period (65.5 Mya to $1.8 \mathrm{Mya}$ ) was marked by a cooling trend from tropics to ice age. At its beginning much of the earth was tropical and subtropical and reached a thermal maximum during the Eocene at about 55.8 Mya. The warm and moist Eocene and Oligocene epochs witnessed the second peak in the diversification of placental mammals that was facilitated by a combination of events. Firstly, a spread of dense forests and angiosperm plants at the expense of archaic gymnosperms, a trend that actually began in the Cretaceous (Bininda-Emonds et al., 2007; Berendse and Scheffer, 2009). Secondly, the extinction of small-bodied multituberculate mammals that had been competing with the placentals. Lastly, a spike in oxygen concentrations in the earth's atmosphere in the Eocene and Oligocene; high oxygen levels are necessary for the physiology of placental reproduction.

This correlation between an increase in atmospheric oxygen and placental body size and diversity began when placental mammals first appeared in the Cretaceous (93 - 
120 Mya). Shortly thereafter, however, oxygen levels and placental diversity fell and remained low for long periods and across the K-Pg boundary, then peaked again in the Eocene and continued through the Tertiary (Falkowski et al. 2005). It culminated in the megafauna of mammals that characterized the subsequent Quaternary period. The ancestors of today's elephants were part of this Eocene “explosion” of megafauna (Deraniyagala, 1955).

India crashed into Laurasia during the Oligocene (35 55 Mya) forming the Himalayas (Aitchinson et al., 2007). As the climate cooled towards the end of the Oligocene, glaciation in Antarctica lowered sea levels and opened land bridges (Rohling et al., 1998). Sri Lanka was positioned in the southern hemisphere during that epoch and the Sri Lankan highlands were under an ice cap, leaving behind tell-tale erratic boulders (Katupotha, 2013). With further global cooling in the Miocene the arctic also developed an ice cap, forests gave way to grasslands. In the Oligocene ancestral carnivores were common and diversifying (Nyakatura and Bininda-Emonds, 2012). Primates with roots in the Paleocene to Eocene boundary, or possibly even earlier (90 Mya) (Tavaré et al., 2002), proliferated with ancestral monkeys and apes in the Miocene (Bowen et al., 2002; Martin 2003). The cooling and drying trend continued into the Pliocene and contributed to the spread of enormous savannahs and grasslands (Osborne, 2008) that supported the diversification of herds of large bodied grazing mammals (artiodactyls and perissodactyls) and their predators (Bobe and Behrensmeyer, 2004; Vislobokova, 2008). The first hominids (Ardipithecus) appeared during the Pliocene in Africa (White et al., 2009). The global cooling that accelerated in the Miocene lead to the development of polar caps in the Pliocene and continued into the Pleistocene ice age.

\section{The Quaternary Period: extinction of megafaunal mammals globally and in Sri Lanka}

The Pleistocene [1.8 Mya to 11.7 Thousand years ago (Kya)] is characterized by the expansion of polar and montane glaciers that at one time covered up to $30 \%$ of the earth's land and sea surfaces. The climate was not static, glacial ice sheets advanced and retreated in cycles, especially in the northern hemisphere, and caused major changes globally in sea levels, habitat, vegetation and faunal composition (Cooper et al., 2015).

Since the Pliocene, Sri Lanka's geographic position has been similar to how it is currently. The periodic low sea levels in the Pleistocene opened the land connection to India (Cooray, 1984) and facilitated a two-way dispersal of fauna across the Palk Strait in repeated waves. The last land bridge was cut off by rising sea levels 5-8 Kya as the Pleistocene gave way to warmer climates and the retreat of northern glaciers in the Holocene (Fleming et al., 1998; Rohling et al., 1998; Milne et al., 2005). Sea levels in Sri Lanka have not changed in the last $3 \mathrm{Ky}$ (Cooray, 1984). During the Pleistocene epoch, Sri Lanka experienced heavy rainfall, stimulating the emergence of rain forest in the country and providing habitat for marsh loving animals (Sumanarathna, 2017). The mammal fauna of Sri Lanka was more varied in the Pleistocene than it is now. Fossil remains in the alluvial deposits of the Sabragumuwa basin, known as the Rathnapura Fauna, indicated the former presence of hippopotamus Hexaprotodon, two species of the genus Rhinoceros, the Indian lion Panthero leo, the red dog Cuon javanicus, the gaur Bibos gaurus (Deraniyagala, 1958) and even the tiger (P. tigris) (Manamendra-Arachchi et al., 2005). It has been suggested that the transition early in the Pleistocene from dry open grassland savannah (habitat favorable for lions) to moist closed-canopy forest (habitat favorable for tigers) in the Holocene underlies the replacement of lions by tigers in the fossil record of Sri Lanka (Manamendra-Arachchi et al., 2005).

On a global scale, 97 of 150 genera of megafaunal mammals (defined as animals $>44 \mathrm{~kg}$ ) went extinct from about 50 Kya until the end of the Pleistocene (Barnosky et al., 2004). Prevailing explanations include human impacts (overhunting, fire), environmental changes, and a combination of both, but primarily driven by climate change (Cooper et al. 2015). Most of these losses were sustained in the glacier-laden northern hemisphere. In the southern hemisphere (except for Australia) 20 of 21 identified mammalian taxa from the past 100 - 200 Kya survived to the present.

The Indian subcontinent preserved a mosaic of ecosystems, ranging from tropical rainforests to grassland savannahs and deserts. This ecological diversity would have supported a large range of organisms. The majority of ancient taxa survived or adapted to substantial ecological pressures in an interconnected mosaic of fragmented habitats in the Asian tropics (Roberts et al., 2014). Notwithstanding, in Sri Lanka several megafauna, all of Indian origin, were lost (Sumanarathna, 2017). Why were they lost in Sri Lanka but not in India? The answer lies most likely in island biogeographical expectations (MacArthur and Wilson, 1967; Heaney, 1986) and local events. Compared to the size of the Indian subcontinent, Sri Lanka had a lesser diversity of vast areas of habitat necessary to sustain the extinct megafaunal mammals. Furthermore, challenges to survival would have been made worse by substantial local climate-related habitat turn-overs during the Pleistocene in Sri Lanka (Katupotha, 1995, 2013).

\section{The impact of humans on megafaunal mammals globally and in Sri Lanka}

Expanding human populations are thought to have exacerbated the impact of climate change on the extinction of megafaunal mammals in the late Pleistocene to Holocene transition (Cooper et al., 2015). Genetic and archaeological evidence from Africa and Asia support a coastally oriented dispersal of modern humans from eastern Africa to southern Asia about 60 - 50 Kya (Mellars et al., 2013), as well as multiple exits, varying terrestrial routes, a sub-divided African source population and a degree of interbreeding with archaic varieties of Homo (Boivin et al., 2013). The most ancient remains of anatomically modern Homo sapiens in South Asia have been found in cave deposits of the Upper Pleistocene in Sri Lanka (Kennedy et al., 1987). These foragers from $20 \mathrm{Kya}$, at the transition from the Pleistocene to the Holocene, exploited semiopen rainforest and forest edge products and influenced 
these habitats (Roberts et al., 2015). In light of the faunal remains of mostly small animals in the middens of these cave dwellers (Perera et al., 2011) it seems unlikely that this population of early human hunter-gatherers had a major role on the extinction of the island's megafauna.

That is not to say that humans have not impacted Sri Lankan megafauna; one example being the elephant. Selective trophy hunting and the massive export of Sri Lankan elephants (for labor, ceremony and warfare) over the last 2-3 millennia (Jayewardene, 1994) may be responsible for the low proportion (less than $8 \%$ ) of tusked males in Sri Lanka, compared to $45-90 \%$ of tuskers on the Indian subcontinent or nearly 100\% in Sumatra (Kurt et al., 1995). The scarcity of tuskers in Sri Lanka has been attributed also to natural variation among geographically isolated populations (Deraniyagala, 1958), or to the founder effect and genetic drift (Fernando et al., 2000). Notwithstanding, humans did influence elephant populations insofar as the dispersal of elephants from different origins by human traders has resulted in a mixing of mitochondrial DNA among formerly isolated populations in Myanmar, Sri Lanka and India (Fleisher et al., 2001). The scarcity of tuskers in Sri Lanka has stimulated the importation of tuskers from India for ceremonial purposes (Jayewardene, 1994). These domesticated tusked imports are closely managed and their reproductive contribution to wild Sri Lankan elephant populations is doubtful (Kurt et al., 1995).

\section{DIVERSIFICATION OF THE MODERN MAMMAL FAUNA OF SRI LANKA}

Following the Pleistocene extinctions of megafaunal mammals in Sri Lanka, as evident in the fossil record (Sumanarathna, 2017), Sri Lanka was left with the contemporary suite of mammals. Sri Lanka is home to 108 unique taxa of mammals under the umbrella of 91 species and 53 genera (Dittus, 2013) among native land living forms. If marine and introduced land mammals were included there are at least 125 species among at least 77 genera in Sri Lanka (Yapa and Ratnavira, 2013). Sri Lanka represents less than $2 \%$ of the South Asian land area, but harbours nearly $25 \%$ of South Asian mammal species.

The taxonomic classification of Sri Lankan mammals has been dealt with comprehensively by the standard works of Phillips $(1935,1980)$ who uniquely distinguished and described the subspecies among the different species of mammals. Phillips' work was updated by Eisenberg and McKay (1970) and reviewed recently by Dittus (2013). Colorful illustration and descriptions of mammals, mostly at the level of the species, can be found in the very readable and comprehensive volume by Yapa and Ratnavira (2013) and as a hand guide by de Silva Wijeyartne (2008). Subspecies of primates have been attractively illustrated by Pethiyagoda et al. (2012) and Nekaris and de Silva Wijeyaratne (2009).

A distinguishing feature of the flora and fauna of Sri Lanka is its high degree of endemism. Endemism is a measure of the degree of taxon divergence from a common, often geographically widespread ancestral type, and reflects phenotypic adaptation to a unique restricted environment.
Sri Lanka's topography and climate are highly variable within a relatively small area of $65,610 \mathrm{~km}^{2}$, and the island's generally high biodiversity has been linked to localized floral and faunal trait adaptations (Eisenberg and McKay, 1970; Ashton et al., 1997; Bossuyt et al., 2004; Gunatilleke et al., 2004; Weerakoon and Goonatilake, 2006; Kathriarachchi, 2012). Forests rich in plant species are also rich in animal species, and there is a direct correlation between the numbers of endemic plants and endemic animals found in sample plots of forests (Figure 4.6, Green and Gunawardena, 1997). Mammals are but one radiation in a web of interactions among substrate, flora and fauna, and given almost 1000 endemic angiosperms in Sri Lanka (listed by Wijesundara et al., 2012) it is not surprising that mammals, too, would show a high degree of endemism (Dittus, 2013).

\section{Species, subspecies and the Evolutionary Significant Unit (ESU)}

Given that mammalian phenotypes vary geographically within a species, and some of these population variants are distinct and unique to Sri Lanka, or endemic, it raises the question on which taxonomic level should we focus for scientific consideration and conservation management? From the point of view of unravelling evolutionary trajectories as well as conservation, the focus should be on the adaptive diversity across the range of a taxon, which reflects its evolutionary success (Moritz, 2002; Hey et al., 2003). Traditionally, intra-specific variation in mammals has been documented and taxonomically classified by the use of subspecies. In other words, the focus of attention should be at the taxonomic level of the subspecies rather than the species. This is particularly so for mammals, where conservative taxonomic tradition has assigned subspecies status to phenotypic variants among populations where ichthyologists or herpetologists, for example, would assign species status.

To give weight to intra-specific variation for the practice of conservation management, the idea of the Evolutionary Significant Unit (ESU) has been introduced (Ryder, 1986). The ESU is an operational concept designating groups of organisms that should be managed separately (Vogler and DeSalle, 1994). The identification of ESUs is based on concordance between sets of data (genetic, morphological, ecological, behavioural) as outlined, for example, by Mortiz (1994). The ESU therefore is a population unit that merits separate management and has a high priority for conservation (Crandall et al., 2000).

While genetic information is a desirable back-up for deciding ESU identity, in practice it is rarely available, whereas historically traditional phenotypic descriptions and morphometric analyses often have been well documented for subspecies, particularly for the Sri Lankan mammals. O'Brien and Mayr (1991) suggested that subspecies are logical conservation units because members of a subspecies share a unique geographic range or habitat, a group of phylogenetically concordant phenotypic characters, and a unique natural history relative to other subdivisions of the species. Dittus (2013) outlined the rationale for the importance of a focus on subspecies as ESU's applied 
to Sri Lankan mammals. The approach is buttressed by comparing the prevalence of endemic mammals at different taxonomic levels; 3 of 53 genera $(6 \%)$, and 22 of 91 species (24\%) are endemic, but incorporating subspecies, the majority 69 of 108 (64\%) Sri Lankan land-living indigenous mammal taxa are diversified as endemics.

\section{The environmental arena for mammalian diversification}

Climate, and to some extent soil, interact to determine vegetation form, which in turn influence mammalian ecology and faunal composition (Eisenberg, 1981). Eisenberg and McKay (1970) updated the nomenclature of Phillips (1935, and revised in 1980) and confirmed and extended the ranges of known named forms, basing their revisions on museum collections as well as on field observations. These authors also commented on the proposed validity of subspecies, and analyzed the distribution of mammalian fauna in relation to habitat types.

Following the climate maps of Mueller-Dombois and Sirisena (1967), Eisenberg and McKay (1970) recognized seven different phyto-climatic zones (Figure 3) and related the distribution of terrestrial mammalian taxa accordingly. The lowland arid zone (A) supports dry monsoon scrub jungle and grassland that occur in the extreme north and northwest (A1) and extreme southeast (A2) of the island. The most extensive area (B) includes the lowland dry monsoon forest and grassland of what is commonly known as the "dry zone." A belt of transitional intermonsoon forest (C) separates the dry zone from the wet zone. Rainforests in the south-west and the central massif of the island occur below $1000 \mathrm{~m}$ (D1), between 1000 $\mathrm{m}$ to $1500 \mathrm{~m}$ (D2), and above $1500 \mathrm{~m}$ (D3). The phytoclimatic zones differ in rainfall, temperature, months of drought, floral diversity, endemicity and forest productivity (Table 1). The boundaries between these habitat types are inexact and local variations occur. For example, in zone D3 Wijesinghe et al. (1993) distinguish between and "intermediate" and "wet" montane zones. Floristic and habitat variations occur on a finer scale within the dry zone (e.g., Dittus, 1977a, 1985a; Perera, 2012), lowland wet zone (Gunatilleke et al., 2006; Kathriarachchi, 2012) and montane wet zone (Wijesundara, 2012). Variations in habitat properties have also been assessed, under GAP analyses, with a view towards watershed management and ecosystem conservation (Jayasuriya et al., 2006) and the reduction of forest cover loss (Mattsson et al., 2012). Such data would be invaluable for future ecological studies and conservation applications (Pethiyagoda, 2012b; Miththapala, 2015).

Regardless of zonal classifications, the contrasts and gradients in habitat constitute the different environmental contexts wherein mammalian phenotypic adaptations

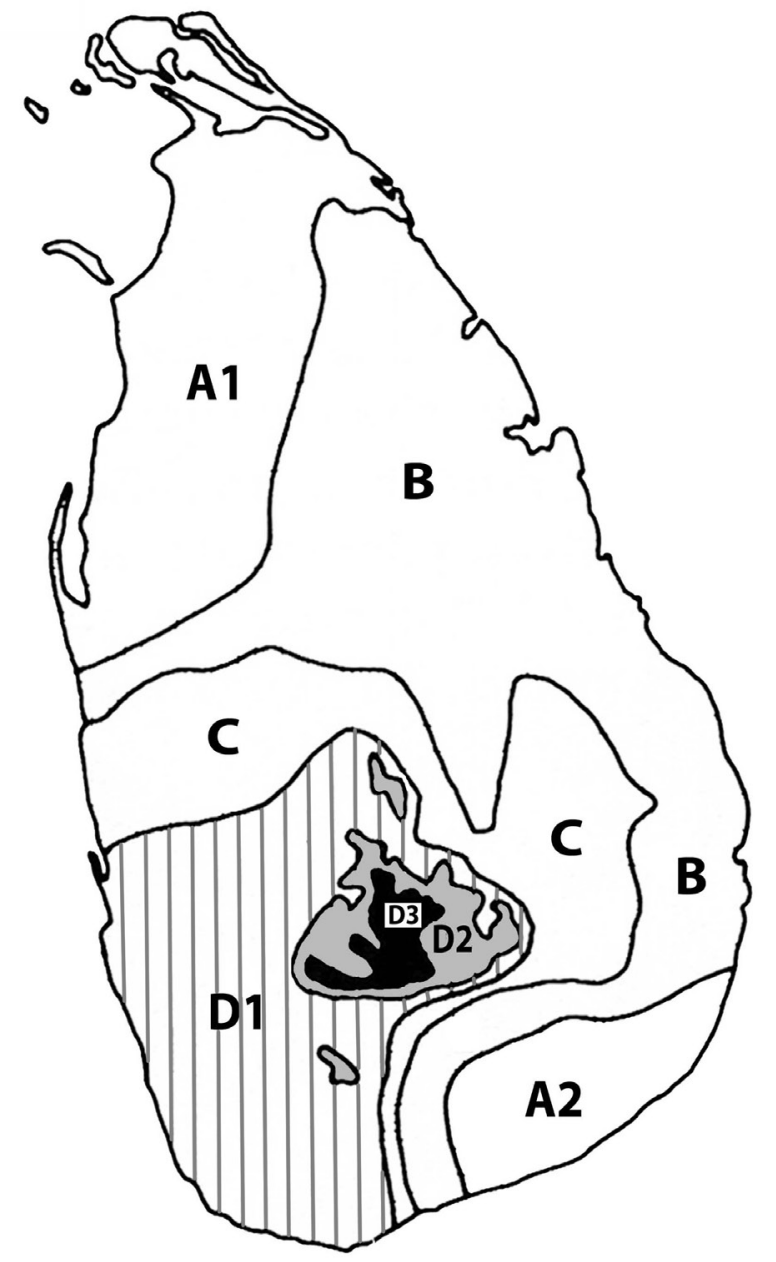

Figure 3: The climatic zones of Sri Lanka are: arid lowlands (A1 and A2), dry zone lowland (B), intermediate zone (C), rainforests of the lowland (D1, striped), midland (D2, dark gray) and montane regions (D3, black). 
evolved. Eisenberg and McKay (1970) pointed out that all of the major ecological feeding niches are filled by Sri Lankan mammals, but compared to that of South India the mammalian fauna of Sri Lanka is less diversified; there being fewer species to fill these niches. This suggests firstly, that ecological niches of Sri Lankan mammals are broader than on the subcontinent, and secondly, that this greater niche breadth is subdivided among subspecies or ESUs. The latter proposition was examined earlier (Dittus, 2013). The emphasis here is on the role of habitat in the geographic distribution and conservation of mammalian diversity.

Table 1: Climatic and biotic properties typical of the major climatic zones and forest types of Sri Lanka.

\begin{tabular}{lllllll}
\hline & $\begin{array}{l}\text { Arid } \\
\text { monsoon } \\
\text { forest }\end{array}$ & $\begin{array}{l}\text { Dry } \\
\text { monsoon } \\
\text { forest }\end{array}$ & $\begin{array}{l}\text { Moist } \\
\text { Monsoon } \\
\text { forest }\end{array}$ & $\begin{array}{l}\text { Wet } \\
\text { Lowland } \\
\text { rainforest }\end{array}$ & $\begin{array}{l}\text { Sub } \\
\text { montane } \\
\text { forest }\end{array}$ & $\begin{array}{l}\text { Montane } \\
\text { forest }\end{array}$ \\
\hline Climate zone & $\mathrm{A}$ & $\mathrm{B}$ & $\mathrm{C}$ & $\mathrm{D} 1$ & $\mathrm{D} 2$ & $\mathrm{D} 3$ \\
Elevation m.a.s.l. & $0-500$ & $0-500$ & $0-1000$ & $0-1000$ & $1000-1500$ & $1500-2500$ \\
Annual rainfall, mm & $<1000$ & $1000-1900$ & $1900-2500$ & $2500-5000$ & $2500-5000$ & $2500-5000$ \\
Mean annual Temperature, ${ }^{\circ} \mathrm{C}$ & 27 & 27 & $25-27$ & $>20$ & $15-20$ & 15 \\
Number of dry months & $5-6$ & $3-5$ & 3 & 0 & 0 & 0 \\
Floral diversity & Very low & low & moderate & high & high & moderate \\
Floristic endemism & low & low & & high & high & high \\
Productivity, dry weight: $\mathrm{mT} / \mathrm{ha} / \mathrm{y}$ & 3 & $3-5.6$ & & $>6.4$ & & 5.0 \\
\hline
\end{tabular}

Table 2: The numbers of (a) native uniquely named terrestrial mammal taxa, separated according to the numbers of (b) non-endemic species, (c) endemic species and genera, and (d) endemic subspecies that occur in all forest types in Sri Lanka (Summary of Appendix 1).

\begin{tabular}{|c|c|c|c|c|c|}
\hline Order/Family & $\begin{array}{l}\text { a: } \\
\text { Total unique } \\
\text { named taxa }\end{array}$ & $\begin{array}{l}\text { b: } \\
\text { Non-endemic } \\
\text { species }\end{array}$ & $\begin{array}{l}\text { c: } \\
\text { Endemic } \\
\text { species/genera * }\end{array}$ & $\begin{array}{l}\text { d: } \\
\text { Endemic } \\
\text { subspecies }\end{array}$ & $\begin{array}{l}\text { Percent total } \\
\text { endemics }\end{array}$ \\
\hline Insectivores (shrews) & 11 & 2 & $5 / 2 *$ & 2 & 81.8 \\
\hline Chiroptera (bats) & 29 & 20 & - & 9 & 31 \\
\hline \multicolumn{6}{|l|}{ Primates } \\
\hline Lorisidae (loris) & 4 & - & 1 & 3 & 100 \\
\hline Cercopithecidae (monkeys) & 8 & - & 2 & 6 & 100 \\
\hline Pholidota (pangolin) & 1 & 1 & - & - & 0 \\
\hline \multicolumn{6}{|l|}{ Rodentia } \\
\hline Histricidae (porcupine) & 1 & 1 & - & - & 0 \\
\hline Sciuridae (squirrels) & 10 & 1 & 2 & 7 & 90 \\
\hline Muridae (rats \& mice) & 18 & 6 & $4 / 1^{*}$ & 7 & 66.7 \\
\hline Lagomorpha (hare) & 1 & - & - & 1 & 100 \\
\hline \multicolumn{6}{|l|}{ Carnivora } \\
\hline Mustelidae (otter) & 1 & 1 & - & - & 0 \\
\hline Canidae (jackal) & 1 & - & - & 1 & 100 \\
\hline Ursidae (sloth bear) & 1 & - & - & 1 & 100 \\
\hline $\begin{array}{l}\text { Viverridae } \\
\text { (mongooses \& civets) }\end{array}$ & 11 & 3 & 3 & 5 & 72.7 \\
\hline Felidae (leopards, cats) & 4 & 2 & - & 2 & 50 \\
\hline $\begin{array}{l}\text { Artiodactyla (spotted deer, } \\
\text { sambar, pig, chevrotain) }\end{array}$ & 6 & 2 & 2 & 2 & 66.7 \\
\hline Proboscidea (elephant) & 1 & - & - & 1 & 100 \\
\hline Totals & 108 & 39 & 19/3* & 47 & 63.9 \\
\hline
\end{tabular}


Table 3. The distribution of the numbers of native uniquely named terrestrial mammal taxa, $\mathrm{N}$, endemic subspecies $(N)$, endemic species $(\mathbf{N})$ and endemic genera $\left(\mathrm{N}^{*}\right)$ among the major phyto-climatic zones of Sri Lanka.

\begin{tabular}{|c|c|c|c|c|c|c|}
\hline Order/Family & $\mathbf{A 1}+\mathbf{A} 2$ & B & $\mathbf{C}$ & D1 & D2 & D3 \\
\hline Insectivores (shrews) & 1 & 1 & 1 & $3(1)$ & $7\left(2,3,1^{*}\right)$ & $7\left(1,3,2^{*}\right)$ \\
\hline Chiroptera (bats) & $15(4)$ & $19(5)$ & $22(2)$ & $24(7)$ & $16(6)$ & $6(2)$ \\
\hline \multicolumn{7}{|l|}{ Primates } \\
\hline Lorisidae (loris) & $1(1)$ & $1(1)$ & $2(2)$ & $2(2)$ & $1(1)$ & $1(\mathbf{1})$ \\
\hline Cercopithecidae (monkeys) & $3(1,2)$ & $3(1,2)$ & $3(1,2)$ & $3(1,2)$ & $2(2)$ & $2(2)$ \\
\hline Pholidota (pangolin) & 1 & 1 & 1 & 1 & 1 & 0 \\
\hline \multicolumn{7}{|l|}{ Rodentia } \\
\hline Histricidae (porcupine) & 1 & 1 & 1 & 1 & 1 & 1 \\
\hline Sciuridae (squirrels) & $3(2)$ & $3(1, \mathbf{1})$ & $3(1, \mathbf{1})$ & $5(3,2)$ & $6(4,2)$ & $5(3,2)$ \\
\hline Muridae (rats \& mice) & $10(5)$ & $11(4,1)$ & $10(4, \mathbf{1})$ & $9(5)$ & $11(6,2,1 *)$ & $7(2,2,1 *)$ \\
\hline Lagomorpha (hare) & $1(1)$ & $1(1)$ & $1(1)$ & $1(1)$ & $1(1)$ & $1(1)$ \\
\hline \multicolumn{7}{|l|}{ Carnivora } \\
\hline Mustelidae (otter) & 1 & 1 & 1 & 1 & 1 & 1 \\
\hline Canidae (jackal) & $1(1)$ & $1(1)$ & $1(1)$ & $1(1)$ & $1(1)$ & 0 \\
\hline Ursidae (sloth bear) & $1(1)$ & $1(1)$ & $1(1)$ & 0 & 0 & 0 \\
\hline Viverridae (mongoose \& civets) & $6(3)$ & $8(3,2)$ & $6(3,1)$ & $5(3,1)$ & $7(3,2)$ & $5(1,2)$ \\
\hline Felidae (leopard \& small cats) & $4(2)$ & $4(2)$ & $3(2)$ & $3(2)$ & $2(2)$ & $2(2)$ \\
\hline \multicolumn{7}{|l|}{ Artiodactyla } \\
\hline Suidae (wildboar) & 1 & 1 & 1 & 1 & 1 & 1 \\
\hline $\begin{array}{l}\text { Cervidae (spotted deer, } \\
\text { sambar, muntjac) }\end{array}$ & $3(2)$ & $3(2)$ & $3(2)$ & $2(2)$ & $2(1)$ & $1(1)$ \\
\hline Tragulidae (chevrotain) & $1(\mathbf{1})$ & $1(\mathbf{1})$ & $1(1)$ & $1(\mathbf{1})$ & $1(\mathbf{1})$ & $1(\mathbf{1})$ \\
\hline Proboscidea (elephant) & $1(1)$ & $1(1)$ & $1(1)$ & $1(1)$ & $1(1)$ & $1(1)$ \\
\hline
\end{tabular}

The diversity of mammals in relation to their biogeography

Taking habitat type as a proxy for potential ecological niche specialization, it was useful to examine mammalian phenotypic diversity at the level of the species and subspecies and its relation to this proxy. A compilation of this data (Appendix 1) was based primarily on Phillips (1980) and Eisenberg and McKay (1970) who considered subspecies in relation to habitat. Where these publications differ in subspecies designations, the more conservative application of Eisenberg and McKay (1970) was followed. The nomenclature for genera and species was updated to conform to recent taxonomic revisions as referenced by authors in Appendix 1. With a few exceptions, subspecies designations have not been closely scrutinized in the recent literature.

The data of Appendix 1 were summarized in relation to the numbers of endemic and non-endemic taxa (genera, species and subspecies) according to taxonomic Order and Family (Table 2) and to the distribution of these taxa among the different phyto-climatic zones (Table 3 ).

Among the 9 land-living orders of mammals of Sri Lanka, there are 91 species among 53 genera. Of these, $22(24 \%)$ are endemic species. Among polytypic orders the proportions of endemic species is highest among insectivores $(70 \%)$ and primates $(60 \%)$, being nearly twice those found among rodents (32\%) and Artiodactyla (33\%), and more than among the carnivores (19\%). Bats have no endemic species. The Carnivora (5 Families) and Artiodactyla (3 Families) have one and two endemic species, respectively. There are no endemic species among the geographically widespread monotypic orders (elephants and hares) or monotypic families (otters, sloth bears).

Mammalian diversity and endemism come to the fore with a finer resolution when incorporating subspecies in the compilation. There are 108 documented unique named taxa at the level of the species or subspecies and more than half $(64 \%)$ of these are endemic (compared to only $24 \%$ of endemic species). The proportions of all endemic forms below the level of the genus is highest among the primates $(83 \%$ to $100 \%)$, moderately high $(67 \%$ to $82 \%)$ in the insectivores, rodents, carnivores and ungulates, and relatively low (31\%) among the bats. Among the monotypic orders, the elephant and hare are considered Sri Lankan subspecies. Similarly, among the monotypic genera of Artiodactyla, the spotted deer and possibly the sambar are peculiar subspecies (Table 2).

Mammal taxa differed in their geographic distribution 
Table 4: Comparison of the distribution of non-endemic and endemic mammal taxa (genera, species and subspecies) and the rates of taxonomic differentiation across different phyto-climatic zones.

\begin{tabular}{lrrrrrr}
\hline \multirow{2}{*}{ Sri Lanka mammals } & $\mathbf{7 1 + A 2}$ & B & C & D1 & D2 & D3 \\
\cline { 2 - 8 } & 55 & 62 & 62 & 64 & 62 & 42 \\
\hline All named taxa & 28 & 32 & 35 & 30 & 18 & 12 \\
\hline All non-endemic taxa & 27 & 30 & 27 & 34 & 44 & 30 \\
\hline All endemic taxa & 0 & 0 & 0 & 0 & 2 & 3 \\
\hline \multicolumn{1}{c}{ Endemic genera } & 2 & 6 & 5 & 6 & 12 & 13 \\
\hline \multicolumn{1}{c}{ Endemic species } & 25 & 24 & 22 & 28 & 29 & 14 \\
\hline \multicolumn{1}{c}{ Endemic subspecies } & 49.1 & 48.4 & 43.5 & 53.1 & 69.4 & 71.4 \\
\hline \% All endemic taxa & 8.0 & 25.0 & 22.7 & 21.4 & 51.7 & 114.3 \\
\hline $\begin{array}{l}\text { Ratio (\%) [endemic } \\
\text { species + genera] : } \\
\text { endemic subspecies }\end{array}$ & & & & & & \\
\hline
\end{tabular}

across climatic zones and in the degree of endemic differentiation (Table 3). The fewest numbers of named taxa occurred in the extremes of the climate spectrum, namely the arid zone (A1 and A2) and the very restricted montane zone (D3). These two extremes differed markedly from each other, however, in the number of endemic taxa that they harboured, $49.1 \%$ (zone A) and $71.4 \%$ (zone D3). The number of named taxa across the more moderate climatic zones (B to D2) was fairly equally distributed at 62 to 64 taxa (Table 4). There was, however, a trend for an increase in the number and proportion of endemic taxa from the dry zones (A and B) and intermediate zone (C) into the wet zones (D). Within the wet zone itself, the proportion of endemics increased with altitude from D1 to D3. Most of the endemic taxa in the wet hill zones (D2 and D3) involved the shrews, squirrels, rats and mice (Table 3). Presumably the high rates of reproduction and low vagility among these small bodied mammals promoted rapid adaptation to their respective niches, culminating in the evolution of at least three endemic genera Solisorex, Srilankamys and Feroculus (Appendix 1). Assuming in situ evolution from endemic subspecies to higher endemic taxa, differences in the rate of natural selection (phenotypic change) towards niche specialization among all Sri Lankan mammals would be reflected by the ratio (endemic species and genera: endemic subspecies). The ratios indicated an increasing taxonomic differentiation from the arid (A: 8\%) to the dry, moist and wet lowlands (B to D1: mean 23\%), submontane (D2: 53\%) and montane zones (D3: 114\%) (Table 4).

Among the primates, Sri Lanka has at least 12 endemic ESU adaptations (subspecies) to the different climatic zones. Of the 5 species, three are also endemic (Macaca sinica, Semnopithecus vetulus and Loris tradigradus). Populations of the gray langur (Semnopithecus priam) and one of the two species of loris (Loris lydekkerianus) have species counterparts in South India. From a regional perspective, Sri Lankan primates show the highest diversity per unit land area among south Asian primates (Dittus, 2013). Similarly, the relatively small bodied civets and mongooses (Viverridae) are taxonomically diverse (Groves et al., 2009) and exhibit endemic taxa in all zones with overall $74 \%$ endemism. The smaller bodied chevrotains (Tragulidae) among the Artiodactyla have evolved one endemic species widespread from the arid zone (A) to the submontane zone (D2) and another is restricted to the montane zone (D3) (Groves and Meijaard, 2005).

The bats have the greatest number of genera and species, are widespread from the arid (zone A) to submontane (zone D2), but are less prevalent in the more restricted land area of upper hills (D3). Bats have no endemic species and relatively few (31\%) endemic subspecies (Table 2). McKay (1984) suggested that the lack of endemic bat species is the outcome of an absence of local effects owed to the bats' potentially high vagility. A similar argument might be made for absent or low endemism among the largest land mammals that can move fairly easily over long distances. This includes the elephant, leopard, wild boar, spotted deer, sambar, sloth bear, and jackal. If body size can be taken as an index of long distance mobility, then there is an inverse relation between the percent of endemic taxa (subspecies to genus) and mammal body size or vagility (Figure 4). The ability to move easily over long distances over the landscape, particularly in the lowland dry zone, would promote gene flow among neighboring populations and counteract local phenotypic ESU distinctiveness. Such gene exchanges, too, may have occurred in geological time between northern Sri Lanka and southern India. The shallow Palk Strait isthmus provided land bridges to India and the opportunity for faunal exchanges during frequent sea-level low-stands in the Pleistocene.

Evolutionary specialization towards endemism in the dry zone $(\mathrm{A}+\mathrm{B})$ was low (Table 4$)$ and is consistent with frequent gene exchange among neighboring populations within Sri Lanka and historically with southern India. Bats and rodents present the highest number of species (Table 2). Unlike other mammals, however, the bats show the highest proportion of non-endemics (Table 2) supporting the notion that, given their vagility, most bat species in Sri Lanka range into distant lands.

Did the montane endemic mammals have more time to differentiate by virtue of being older than mammals of lower elevations? The Pliocene (5.6 to $2.5 \mathrm{Mya}$ ), just prior 


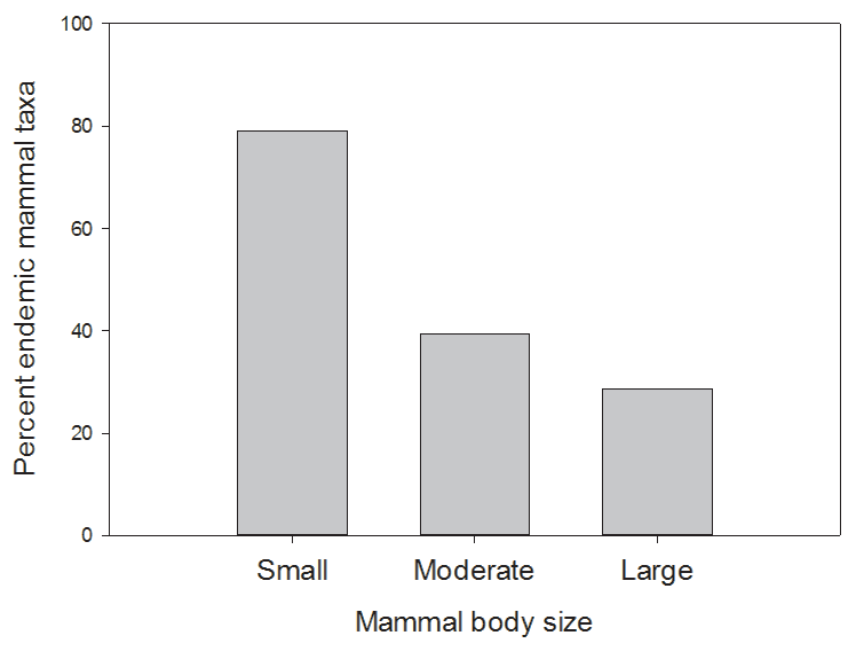

Figure 4: The relation between the prevalence of endemic mammal taxa (subspecies, species and genera) and mammal body size.

to the Pleistocene ice ages, was warmer and sea levels were higher, suggesting that Sri Lankan mammals were marooned on what is now the highlands, the lowlands being under water. With the retreat of the sea to lower levels in the Pleistocene, exposure of the lowlands and the opening of the isthmus to southern India, dispersers from the highlands together with new immigrants from the mainland would retard endemism in newly opened habitats, which now are represented by the lower elevation regions within zones $\mathrm{A} 1, \mathrm{~A} 2, \mathrm{~B}, \mathrm{D} 1$ and $\mathrm{C}$.

For South Asian nonvolant fauna in general, $5-25 \mathrm{~km}$ sea channels have proven substantial barriers to dispersal and island colonization with consequences for genetic diversity (Heaney, 1986). In Sri Lanka, for example, the populations of leopard (Miththapala et al., 1991, 1996) as well as elephant (Fernando et al., 2000) are genetically less diverse than their mainland source counterparts, suggesting genetic founder events. Elephant populations showed further genetic differentiation among different regions within Sri Lanka.

It is appropriate to close these generalized considerations with caveats. The indicated numbers of taxa and their distributions by climatic zone (Appendix 1, Tables 3 and 4) are limited by published reports of a few investigators. Although the biogeographic patterns are apparent, the numerical details are expected to change with future research. The ranges of some taxa, particularly into the zone $\mathrm{C}$ may be greater (or less) than indicated. Most recently, morphometric comparisons among loris populations point to two new subspecies (Gamage et al., 2017 online). Phylogenetic studies, in particular, have uncovered at least five new species that formerly were thought of as subspecies (Groves and Meijaard, 2005; Meegaskumbura et al., 2007; Meegaskumbura and Schneider, 2008; Groves et al., 2009; Dissanayake and Oschida, 2012). Baker and Bradley (2006) estimate that genetic investigations will uncover $>2,000$ new and "cryptic species" worldwide. The trend in our knowledge is for greater rather than lesser species diversity among Sri Lankan mammals. Finally, there is a seemingly unexplained absence of phenotypic diversification among such geographically widespread and moderately vagile monotypic taxa as hares, porcupines, pangolins, and otters. Perhaps future investigations will identify population ESU differentiation?

The above analyses serve to predict which mammalian taxa one might observe in the different phyto-climatic zones of Sri Lanka and point to some hypothetical evolutionary drivers for the observed pattern of taxa differentiation and biogeography. The following section examines the likelihood of actually observing different mammalian taxa, the ecological challenges facing mammals and their conservation status.

\section{THE CONSERVATION OF MAMMALS IN RELATION TO THEIR ECOLOGY AND BIOGEOGRAPHY}

\section{What once there was}

Natural forest covered almost the entire island a few centuries ago comprising the dry zone forests $(48,000$ $\left.\mathrm{km}^{2}\right)$, lowland rainforest $\left(12,500 \mathrm{~km}^{2}\right)$, montane forest $\left(3,000 \mathrm{~km}^{2}\right)$ and unclassified $\left(1,920 \mathrm{~km}^{2}\right)$. Overall closed forest cover has dwindled from $84 \%$ in 1884 to less than 22\% in 2016 (after Legg and Jewell, 1995; GOSL, 2000; FAO, 2005, 2010). Forest loss was greatest in the wet zone, particularly in the lowlands, where most humans dwell. Of the original lowland rainforests (D1) less than $2.1 \%\left(141 \mathrm{~km}^{2}\right)$ now remain as fragmented, degraded and isolated patches throughout the lowland wet zone (Kathriarachchi, 2012). Likewise, the submontane and montane ecoregion forests have been reduced to $1 \%$ (30 $\mathrm{km}^{2}$ ) comprising isolated fragments of degraded habitat (Wijesundara, 2012).

Published descriptions of the lowland and montane forests give details about species composition, ecological properties, threats facing them, the fauna that they support and conservation status (Gunatilleke and Ashton, 1987; Gunatilleke and Gunatilleke, 1991; Ashton et al., 1997; Wikramanayake and Gunatilleke, 2002a, b, c; Kathriarachchi, 2012; Wijesundara, 2012). Although there are 31 different protected areas in the lowland rainforest region, and nine at higher elevations, most are small in 
Table 5: The estimated numbers [n] and areas of extents of different categories of protected areas according to phyto-climatic zone.

\begin{tabular}{|c|c|c|c|c|c|c|c|c|}
\hline $\begin{array}{l}\text { Protected areas/climate } \\
\text { zone }\end{array}$ & $\begin{array}{c}\mathrm{A} 1 \\
\mathbf{k m}^{2}[\mathrm{n}]\end{array}$ & $\begin{array}{c}\text { A2 } \\
\mathbf{k m}^{2}[\mathbf{n}]\end{array}$ & $\begin{array}{c}\text { B } \\
\mathbf{k m}^{2}[\mathbf{n}]\end{array}$ & $\begin{array}{c}\mathrm{C} \\
\mathbf{k m}^{2} \\
{[\mathbf{n}]} \\
\end{array}$ & $\begin{array}{c}\text { D1 } \\
\text { km² }^{2}[\mathrm{n}]\end{array}$ & $\begin{array}{l}\text { D2 } \\
\mathbf{k m}^{2} \\
{[\mathbf{n}]} \\
\end{array}$ & $\begin{array}{c}\text { D3 } \\
\text { km² }^{2}[\mathbf{n}]\end{array}$ & $\begin{array}{c}\text { Total } \\
\mathbf{k m}^{2}[\mathbf{n}]\end{array}$ \\
\hline \multicolumn{9}{|l|}{$\begin{array}{l}\text { Dept Wildlife } \\
\text { Conservation }\end{array}$} \\
\hline National Parks & 404 [3] & $3,407[7]$ & $1,980[10]$ & $371[1]$ & $>1[1]$ & & $32[2]$ & $6,194[24]$ \\
\hline Strict Nature Reserve & & $289[1]$ & $15[1]$ & & & & $11[1]$ & $315[3]$ \\
\hline Nature Reserves & & & $533[3]$ & & & & $80[1]$ & $613[4]$ \\
\hline \multicolumn{9}{|l|}{ Sanctuaries } \\
\hline $\begin{array}{l}\text { Forest, } \\
\text { predominantly }\end{array}$ & $41[2]$ & 94 [4] & $942[11]$ & $440[2]^{1}$ & $7[6]$ & $130[2]^{2}$ & & $1,654[27]$ \\
\hline Wetlands \& mangrove & & $75[2]$ & 39 [2] & & $76[9]$ & & & $190[13]$ \\
\hline Tanks & $22[1]$ & $43[1]$ & $373[6]$ & & $11[1]$ & & & 449 [9] \\
\hline \multicolumn{9}{|l|}{ Dept Forestry } \\
\hline $\begin{array}{l}\text { Biosphere Conservation } \\
\text { Area }\end{array}$ & & & $250[1]$ & & $109[1]$ & & & $359[2]$ \\
\hline Conservation Forest & & & & $112[1]^{3}$ & 133 [12] & & & $245[13]$ \\
\hline Other important FRs & $154[1]$ & & & & $59[1]$ & & & $213[2]$ \\
\hline Total & $621[7]$ & $3,908[15]$ & $4,132[34]$ & $923[4]$ & $395[31]$ & $130[2]^{2}$ & $123[4]^{2}$ & $10,232[97]$ \\
\hline
\end{tabular}

areas, with exception of the Sinharaja National Heritage Wilderness Area $\left(112 \mathrm{~km}^{2}\right)$ in the lowland rainforest and the Peak Wilderness area $\left(120 \mathrm{~km}^{2}\right)$ that straddles the submontane and montane regions (Table 5).

The montane and/or submontane (D2, D3) forests constitute the exclusive homes for 22 mammalian taxa, and the partial homes for an additional 38 taxa. Eight of the taxa that are confined to the highlands are endemics (genus, species or subspecies) and all of them are either Endangered or Critically Endangered (MOE, 2012; Dittus, 2013; IUCN 2017). The highlands are the exclusive habitat for the highest proportion $(8 / 14=53 \%)$ of endangered endemic mammals in Sri Lanka (Table 6). The few PAs in these hills are small and subject to continuous habitat loss and degradation (Wikramanayake and Gunatilleke, 2002c; Wijesundara, 2012). Pethiyagoda (2012a) described most of the mammals encountered in or near the Horton Plains National Park of zone D3. Mammals that potentially conflict with humans outside of these PAs are persecuted (Gamage et al., 2010; Dittus, 2012; Kittle et al., 2014). The critically endangered endemic montane toque macaque (Macaca sinica opisthomelas) lacks even legal protection.

The Sinharaja is the largest reservation for lowland rainforest biodiversity and is supplemented by many smaller forest fragments that offer suitable habitat especially for mammals of relatively small body sizes and limited home ranges (Table 5). Jayasekera et al. (2007) observed 14 species of arboreal and terrestrial mammals typical of the area at fruit traps, and Ratnaweera and Wijesinghe (2009) suggested that populations of fruit eating rainforest rodents are limited by seasonal fruit shortages. Notably, the wet-zone toque macaque (M. s. aurifons) was rare inside forested areas, but was common at the forest peripheries in keeping with its ecological adaptation to "edge" habitats (Richard et al., 1989). Wijesinghe and Brooke (2005) and Wijesinghe (2012) have pointed out, however, that habitat disturbance, as occurs on forest edges, negatively impacts the small bodied mammal endemic niche specialists more than the non-endemic ones and may lead to a shift in faunal composition in such areas. The endangered endemic leopard (Panthera pardus kotiya) is the apex predator in Sri Lanka and its survival is best served by large extents of PAs of natural forest and protected corridors of vegetation connecting smaller areas (Kittle et al. 2014, 2017). The leopard's versatile diet, which may include more than $60 \%$ porcupines in areas where other prey are rare, contributes to the predator's success outside of protected areas.

The lowland rainforest region north of the Kalu river lacks undisturbed original forest altogether. A moderately disturbed forest of about $21 \mathrm{~km}^{2}$, the Kalatuwawa and Labugama reservoirs, which supply drinking water to the city of Colombo, is valuable habitat, particularly for 
Table 6: The distribution among phyto-climatic zones of Endangered and Critically Endangered endemic mammal taxa (*subspecies, ${ }^{* *}$ species, $* * *$ genus).

\begin{tabular}{|c|c|c|}
\hline Species/subspecies & $\begin{array}{l}\text { Phyto-climatic } \\
\text { zone }\end{array}$ & IUCN Red List status \\
\hline \multicolumn{3}{|l|}{ Order Insectivora } \\
\hline *** Feroculus feroculus & D3 & Endangered $^{1}$ \\
\hline \multicolumn{3}{|c|}{ Kelaart's Long-tailed Shrew } \\
\hline *** Solisorex personi & D2, D3 & Endangered $^{1}$ \\
\hline \multicolumn{3}{|c|}{ Pearson's Long-clawed Shrew } \\
\hline ** Suncus fellowes-gordoni & D3 & Endangered $^{1}$ \\
\hline \multicolumn{3}{|l|}{ Ceylon Pigmy Shrew } \\
\hline ** Suncus zeylanicus & $\mathrm{D} 2$ & Endangered $^{1}$ \\
\hline \multicolumn{3}{|l|}{ Sri Lanka Jungle Shrew } \\
\hline \multicolumn{3}{|l|}{ Order Rodentia, Family Muridae } \\
\hline ** Rattus montanus & D3 & Endangered $^{1}$ \\
\hline \multicolumn{3}{|l|}{ Sri Lanka Bi-coloured Rat } \\
\hline ** Vandeleuria nolthenii & D2, D3 & Endangered $^{1}$ \\
\hline \multicolumn{3}{|c|}{ Sri Lanka Long-tailed Tree Mouse } \\
\hline ** Mus fernandoni & $\mathrm{A}, \mathrm{B}, \mathrm{C}$ & Endangered $^{1}$ \\
\hline Sri Lanka Spiny Mouse & & \\
\hline
\end{tabular}

\begin{tabular}{|c|c|c|}
\hline \multicolumn{3}{|l|}{ Oder Proboscidea } \\
\hline ** Elephas maximus & $\mathrm{A}, \mathrm{B}, \mathrm{C}$ (primarily) & Endangered $^{1}$ \\
\hline \multicolumn{3}{|l|}{ Sri Lanka Elephant } \\
\hline \multicolumn{3}{|l|}{ Order Primates } \\
\hline$* *$ Loris tardigradus & D1 & Endangered $^{1}$ \\
\hline \multicolumn{3}{|l|}{ Red Slender Loris } \\
\hline * Loris lydekkerianus nycticeboides & D3 & Critically Endangered ${ }^{2,3}$ \\
\hline \multicolumn{3}{|l|}{ Montane Slender Loris } \\
\hline * Macaca sinica opisthomelas & D3 & Critically Endangered $^{4}$ \\
\hline \multicolumn{3}{|l|}{ Montane Toque Macaque } \\
\hline * Semnopithecus vetulus nestor & D1 & Critically Endangered $^{3}$ \\
\hline \multicolumn{3}{|l|}{ Western Purple-faced Langur } \\
\hline \multicolumn{3}{|l|}{ Order Canivora, Family Felidae } \\
\hline ** Prionailurus rubiginosus & All zones & Endangered $^{1}$ \\
\hline \multicolumn{3}{|l|}{ Sri Lanka Rusty Spotted Cat } \\
\hline * Panthera pardus kotiya & All zones & Endangered $^{5}$ \\
\hline Sri Lanka Leopard & & \\
\hline
\end{tabular}

${ }^{1}$ Weerakoon (2012), ${ }^{2}$ Gamage et al. (2014); ${ }^{3}$ Mittermeier et al. (2006); ${ }^{4}$ Dittus and Gamage (2017). ${ }^{5}$ Kittle \& Watson (2008). 


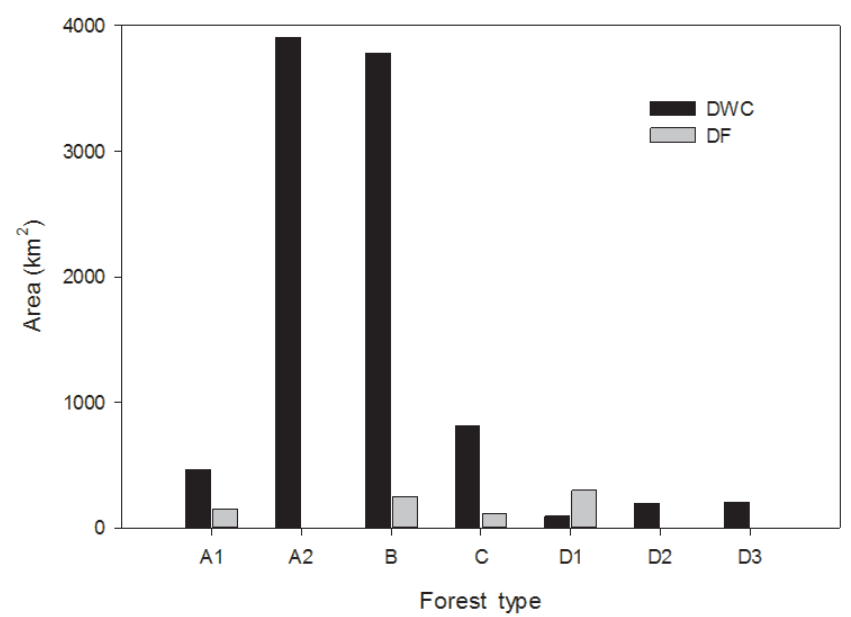

Figure 5: The total size of all protected areas distributed according to phyto-climatic zones and administering government departments.

the Critically Endangered western Purple-faced langur (Semnopithecus vetulus nestor) (Rudran, 2007) and other associated wildlife. Most remaining populations of the western Purple-faced langurs inhabit fragments of secondary forest in plantations or home gardens that face attrition (Dela, 2007). The replanting of silvicultural (pine) plantations with native forest species would contribute ecologically suitable habitat for the support of many species of wildlife in this area (Rudran et al., 2013; Jinie Dela, personal communication).

\section{A close look at the Dry Zone as mammal habitat}

The purpose here is to examine some of the more salient ecological properties of the dry zone habitats in relation to ecological niches suitable for mammals. The dry zone comprises the largest segment (about 70\%) of Sri Lanka's landscapes and the majority of PAs occur there (Figure 5). The extensive dry zone is not uniform in forest cover, forest type and floristic composition owed to regional variations in rainfall, soil, number of months of drought and human activity. It is a mosaic of vegetation types including forestscrub, open grassland, savannah, scrub, as well as modified types (e.g., paddy and chena) as described by Koelmeyer (1958), Andrews (1961), Gaussen et al. (1964), Fernando (1968), Dittus (1977a, 1985a), and Perera (2005). The flora and conservation status of these areas has been reviewed (Wikramanayake and Gunatilleke 2002a; Perera, 2012). The forests of these areas are most often referred to as "Dry Evergreen", "Dry Monsoon", or "Semi-deciduous" and other labels have also been applied (see, Dittus, 1985a).

Structurally, the dry evergreen forest has three layers; a more or less continuous subcanopy of trees (above $5 \mathrm{~m}$ height) over-towered by a discontinuous upper canopy of emergent trees. A layer of shrubs occurs below $5 \mathrm{~m}$. The floristic composition of the sub canopy of trees is generally more stable in species composition than the emergent layer, and its tree species richness (number of species), diversity, and average canopy height are directly related to rainfall amount and drought duration (Dittus 1977a). Therefore, the forests of zone $\mathrm{B}$ are more diverse, richer in species and taller than those of arid zones A (Andrews, 1961; Dittus, 1977a). In addition, regularly recurrent cyclones impact the northeastern coastal forests and occasionally penetrate deeply into the island's central and western interior.
Cyclones cause most damage to the emergent tree layer, and Dittus (1985a) had suggested that the greater geographic variation in species composition typical of this uppermost layer may, in part, be a consequence of regularly recurrent cyclone damage. Cyclones affect not only forest structure directly, but also indirectly by negatively impacting the normally stable relationships between arboreal browsers and tree species composition (Dittus, 1985b). Past disturbance in the dry zone through chena cultivation, fire and two millennia of rice cultivation and irrigation schemes also have changed the character of the old growth forests and the extents of open grasslands and savannah in the dry zone (Gaussen et al., 1964; McKay, 1973; Perera, 2005).

The biological importance of 'Weera': mother tree of the dry zone

The 'Weera' tree (Drypetes sepiaria) is a key floral constituent of dry zone forests, contributing the greatest proportion of trees; from $10 \%$ of all tree stands in the relatively moist regions to more than $50 \%$ in the arid regions such as the Madhu and Panama PAs (Dittus, 1977a). A typical cross section of these forest (Figure 6) in a relatively moist area of Polonnaruwa (1671 mm rainfall, 3-4 months of drought) illustrated that Drypetes plays a dominant ecological role with the greatest Importance Value Index of Curtis and McIntosh (1951) (Dittus, 1977a). Extensive surveys of Sri Lankan forests were carried out in the 1950's in an effort to inventory harvestable timber trees. The Drypetes tree with its gnarled, furrowed and twisted trunks certainly was unsuitable as timber, and was condemned as a "problem junk tree" useful only as fuel wood (Andrews, 1961).

Other than timber, however, the biological properties the Drypetes tree distinguish it as the most important biological asset (arguably second only to water) for sustaining the floral and faunal biodiversity of the dry and arid zones. The tree is a hardy and drought resistant evergreen that does not shed its thick leathery leaves, even in the driest of months. It retains moisture in the soil beneath its canopy, provides year round shelter for plants growing in its shade, and it is a crucial source of fruit for animals at the peak of the annual drought. 'Weera' is most often associated in dry habitats with the 'Palu' tree (Manilkara hexandra) that is similarly drought resistant and forms a discontinuous emergent layer 


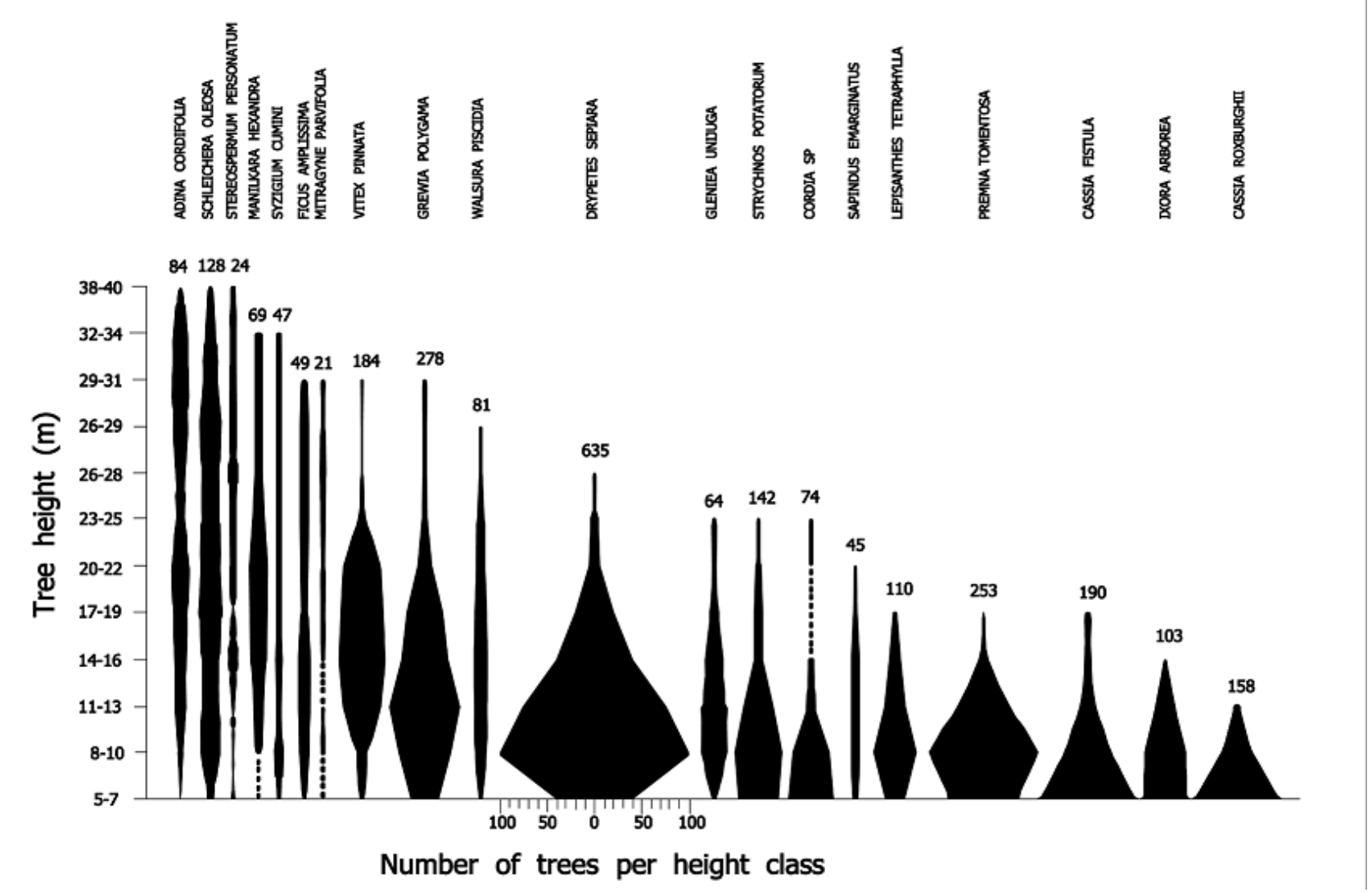

Figure 6: Cross section of a typical dry monsoon forest habitat for dry zone mammals, as at Polonnaruwa, Sri Lanka, indicating the distribution of the major tree species according to the frequency of numbers of trees by their height. (After Dittus, 1977a).

of large shading crowns, albeit, at a far lower densities than 'Weera'. Studies by Hladik and Hladik (1972) have shown that a single average sized fruiting tree of Drypetes produces over 50,000 fruits per annum, or an average of $17.5 \mathrm{~kg}$ of nutrient rich pulp. The seeds themselves provide additional food for animals capable of processing woody seeds (e.g., many rodents). Fruit is produced in prodigious amounts just prior to the drought in April and May. Much of this bounty falls to the ground and dries as "raisins." Animals seek these raisins when many other forests resources have been exhausted at the peak of the drought from June to September. The tree also produces leaf flush in the dry months and this serves as food and moisture for browsers. Drypetes, far from being useless, is a critical component for sustaining the biodiversity of a generally unproductive dry zone that blankets over $70 \%$ of Sri Lanka's land area. The official and unofficial wanton destruction of this tree constitutes an environmental assault matched only by a similar eradication of the wet zone forests in the $19^{\text {th }}$ Century up to the present.

\section{Carrying capacity for mammals of the dry zone}

To the untrained eye a visit to any one of the protected areas of the dry zone forests may impart the impression of bountiful verdant habitat to support animal life. Indeed, wildlife management practices, whereby "problem" elephants, monkeys and other creatures have been translocated to these areas is based on such an uninformed assumption. The bounty of the habitat is an illusion: ecological studies have shown these dry and arid zone protected areas to have the lowest plant productivity among Sri Lankan forests (Table 1) and comparable forest in other tropical regions (Hladik and Hladik, 1972). Consequently, their carrying capacity for mammals is generally low, as illustrated by ecological studies of the Wilpattu and Gal Oya National Parks (Figure 7 and 8). The most common large mammal, the spotted deer (Axis axis) has a crude density of less than 6 deer per $\mathrm{km}^{2}$ at Wilpattu (before the recent war) and even less at Gal Oya. Mammal densities and forest habitat were reduced in most dry zone areas, including the protected ones, through hunting and poaching, especially during the protracted war (Santiapillai and Wijeyamohan, 2003).

Local variations in vegetation type affect mammal species densities. Thus, in areas such as Wilpattu, where the forest understory is widespread, the biomass of browsing species (axis deer, sambar and muntjac) is greater than in sparsely forested areas such as Gal Oya NP. On the flip side, the extensive grasslands and savannah habitats, as found at Gal Oya NP, support greater densities and biomass of grazing mammals (elephant, buffalo and hare) than the closed forest habitats (McKay, 1973).

Elephants, buffalos and sambar, with relatively large body sizes and total biomass (Figure 7), have very few individuals per square kilometer (Figure 8). The herbivores (elephant, axis deer, sambar, buffalo, hare, and langurs) have a generally higher biomass than mammals dependent upon less common or predictable food sources such as fruiting trees, tubers or anthills (Figure 7). Water influences mammal distributions indirectly through its 


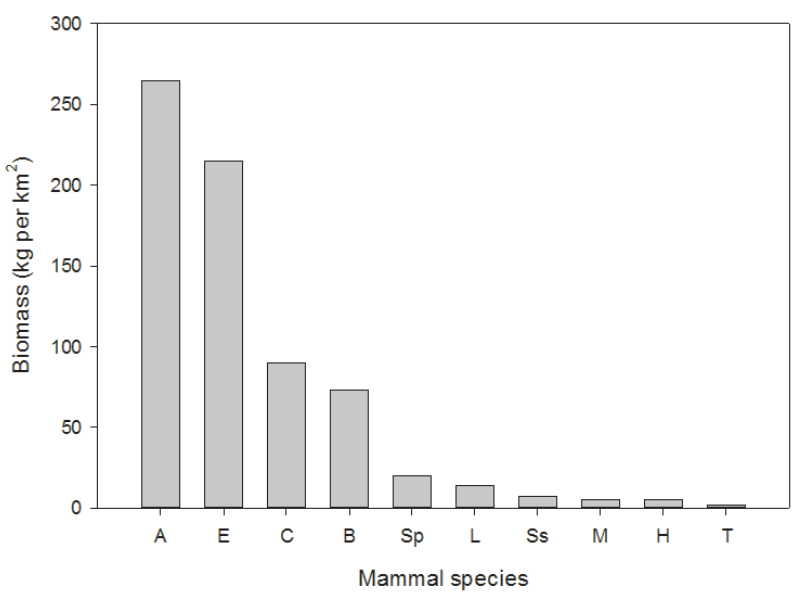

Figure 7: The crude biomass of herbivorous mammals at the Wilpattu National Park (1968-1969) expressed as kilograms per km². Animals are listed in decreasing order of biomass contribution. A=Axis, E=Elephas; $C=$ Cervus, B=Bubalus, Sp $=$ Semnopithecus, $L=$ Lepus, $S s=$ Sus, $M=$ Muntiacus, $H=$ Hystrix, $T=$ Tragulus. (After Eisenberg and Lockhart, 1972).

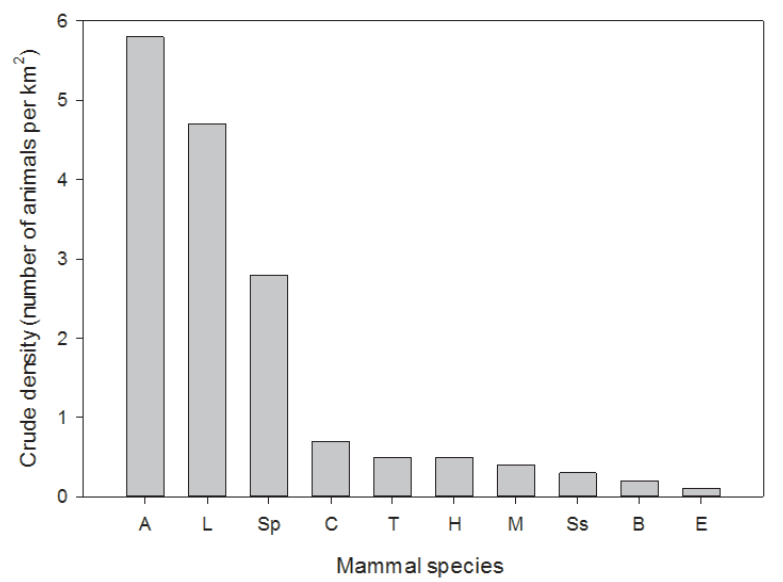

Figure 8: Crude densities of major herbivores in Wilpattu National Park were ranked in the order of numerical abundance; mammal species as in Figure 5. (After Eisenberg and Lockhart, 1972).

effect on plant productivity (i.e., mammal food sources) as well as an open source for drinking. Hladik and Hladik (1972) have shown that plant productivity is greater near permanent water sources, such as some villus $(5 \mathrm{mT} / \mathrm{ha} / \mathrm{yr})$ and alluvial forest than in the dry areas removed from water (3 mT/ha/yr).

Animals differ in their tolerance for dry conditions; the browsing langurs, for example, extract water from leaves (Ripley and Schikele, 1970) whereas the toque macaque requires daily access to free water. Mammals with small body sizes (langurs, macaques, mouse deer, muntjac, civets) tend to be philopatric with relatively small ranges and most are confined to the well-watered areas, the exceptions being the hare and grey mongoose that are common in dry habitat (Eisenberg and Lockhart, 1972). The frugivorous flying fox (Pteropus giganteus) visit the dry parks only seasonally (Eisenberg and Lockhart, 1972). Similarly, mammals of large body size that have the ability to range over long distances are able to compensate for localized shortages in food and water. Cases in point are the well documented movements of elephants (and to a lesser extent buffalo) that shift seasonally over long distances between permanent sources of water and fodder (Eisenberg and Lockhart, 1972; McKay, 1973; McKay and Eisenberg, 1974; Ishwaran, 1983; Fernando et al., 2008; Pastorini et al., 2010, 2013). Elephants prefer to graze (Ishwaran, 1983) but during dry seasons may browse and cause considerable damage to tree crowns (Mueller-Dombois, 1972). The elephants' search for water and fodder may bring them into conflict with humans outside of protected areas (Fernando et al., 2008).

Leopard densities and ranges are dependent upon those of their prey, which in the dry zone PAs comprise large proportions (about 50\%) of axis deer, followed by smaller animals, but virtually no large buffalos and elephants (Eisenberg and Lockhart, 1972, Muckenhirn and Eisenberg, 1973). While quantitative measures of carrying capacity are elusive (Ishwaran, 1981), these observations taken together do suggest a limited capacity for dry zone habitats to support sizeable mammal populations.

Many water dependent mammals are confined to the very restricted areas of permanent water that constitute less than $1 \%$ of these forest or in the protected areas 
located there. Therefore, large tracts of arid zone habitat (A1 and A2) are required to support a few mammal individuals (Figure 8). At Wilpattu and Gal Oya, for example, the crude density of macaques is approximately 0.2- 0.4 individuals per $\mathrm{km}^{2}$. This contrasts starkly with the density of macaques (50-100 individuals per $\mathrm{km}^{2}$ ) or langurs (150-200 individuals per $\left.\mathrm{km}^{2}\right)$ in well-watered productive sites such as Polonnaruwa or in riverine forest (Dittus, 1977b).

Human activity has had a profound effect on dry zone habitats for at least 2000 years. On the one hand, a vast number of ancient irrigation tank cascades provide water and food for humans (Seneviratne, 1987; Bebermeier et al., 2017) and, incidentally, also for wildlife (Geekiyanage and Pushpakumara, 2013). On the other hand, natural forest has been cut and burned for chena cultivation, and shifting agriculture affects the availability and distribution of fodder and the movements of large mammals (McKay 1973, Pastorini et al., 2013). In addition, ever expanding populations of feral buffalo and cattle, particularly over the last 100 years, negatively impact scarce water and food resources; competition with domestic herds is a growing constraint for large mammal populations (Vancuylenberg, 1977; Fernando, 2015b).

In the final analysis, compared to the wet zones, the PAs of the dry zone may be numerous and relatively large in area, but mostly they encompass unproductive habitat with a low crude densities of a diverse mammalian fauna. Protected areas in the moister areas of the dry zone (Kaudulla, Minneriya, Wasgomuwa, Angammedilla, Hurulu) are welcome additions to the network of protected areas to support water-dependent mammals and/or closed forest. Some of these PAs are well known for their large elephant "gatherings" (de Silva Wijeyeratne, 2006). The Wasgomuwa NP has been described as suitable habitat for the sloth bear (Santiapillai and Santiapillai, 1990; Ratnayeke et al., 2007, 2014). The dry zone is latticed by rivers, streams and ancient tank cascades and the associated narrow strips of alluvial forest have been estimated to amount to only $224 \mathrm{~km}^{2}$ in the dry zone (FAO, 2005). Unfortunately, these prime ribbons of riverine forest are subject to the highest rate of annual loss (timber extraction) in the dry zone (FAO, 2005; Mattsson et al., 2012). The conservation of mammalian biodiversity in the dry zone would benefit greatly from protective management of habitats along streams and rivers in keeping with GAP objectives (Jayasuriya, 2006).

\section{Human-animal conflict and misconceptions}

In all climatic zones, the expansion of humans into forested areas has resulted in an influx of pests, such as house and brown rats, which compete with the smaller indigenous mammals (Weerakoon and Goonatilake, 2006). Domestic dogs and cats have increased predator pressure, and many of the larger mammals face being killed as pests, bush meat (deer, pigs, pangolin, hare, and langur monkeys), skins (leopards) (Kittle and Watson, 2003) and ivory (elephants) (Santiapillai et al., 2002). Snares set for bush meat trap other animals, including leopards (Kittle et al. 2014). Humans and their domestic animals also have introduced disease, such as toxoplasmosis (Ekanayake et al., 2004), cryptosporidiosis and a variety of enteric parasites into wild populations of primates (Ekanayake et al., 2006, 2007).

Elephants, langurs and the omnivorous macaques are frequently encountered at sites having a constant supply of human food refuse (temples, tourist kiosks, hotels, municipal garbage dumps, and roadside picnic areas). Refuse sites are an artifact of human activity, attract wildlife and are the main cause for human-animal conflict, particularly with primates (Dittus, 2012). Unguarded agricultural plots are also sites of conflict especially with elephants (Fernando et al., 2005). Locally restricted, but conspicuous public sites with high animal concentrations can lead to a false belief in a countywide overpopulation of monkeys. Such impressions are belied, however, by their low densities in natural areas not affected by humans. It follows that translocation of "problem" monkeys or elephants to protected areas of low carrying capacity contradicts ecological sense and cogent management and causes harm to both wildlife and human communities (Fernando et al., 2012). Scientifically consistent measures of effectively reducing human-animal conflict have yet to be implemented to replace the fallacious but politically expedient knee-jerk reactions to such challenges.

\section{The biogeography and history of mammals in relation to that of the flora and other fauna of Sri Lanka}

The biogeographical patterns observed among mammals run parallel to those of the flora and other fauna of Sri Lanka; together they portray an extraordinary history that is manifest in the nature of Sri Lanka. In keeping with global tropical and subtropical trends towards the dominance of flowering plants (Berendse and Scheffer, 2009), very few Sri Lankan Gymnosperms (cycads), with pre-Devonian roots (400 Mya) (Wachtler, 2016), survive as Gondwanan relics. Only two cycads survive confined to the montane regions ([Table 16] MOE, 2012), and none of the primitive Mesozoic mammals associated with gymnosperm forests survived the Paleogene anywhere. Many megafaunal mammals and their supporting grasslands and savannahs became common and widespread during the Miocene and Pliocene, but as these habitats shrank in the Pleistocene and Holocene many megafauna went extinct.

Sri Lanka has the highest diversity of angiosperms in South Asia with over 3,000 species (nearly 1,000 being endemic), the majority of which are found in the wet and montane zones (Wijesundera et al., 2012). In these plant species-rich and diverse physiographic habitats we find also the highest diversity of mammalian taxa (Weerakoon, 2012a; Dittus, 2013). A similar pattern is evident among the vertebrate (Weerakoon, 2012b) and invertebrate fauna of more ancient origins than mammals, in particular those having low vagility: the amphibians (ManamendraArachchi and Meegaskumbura, 2012), reptiles (Wickramasinghe, 2012), fresh water fish (Goonatilake, 2012), crustaceans (Bahir and Gabadage, 2012), snails (Ranawana and Priyadarshana, 2012), spiders (Benjamin et al., 2012) and others (Bambaradeniya, 2006; MOE, 2012). Taxa whose origins predate the break-up of Gondwana retain their roots as Gondwanan relics with affinities 
to related fauna that have diversified through time as endemics in their respective separated habitats, for example in Sri Lanka and southern India (Bossuyit et al., 2004). Sri Lankan birds, with greater vagility than many other animals, show only a minor trend towards greater diversity and endemism in the wet and montane zones (Kotagama, 1989; Weerakoon and Gunawardena, 2012). Dung beetles, however, buck the trend; they are more diverse and species rich in the dry zone owed to the preponderance of large herbivorous mammals and the expanding herds of cattle - a human artifact (Kudavidanage and Lekamge, 2012).

Most flora and fauna, including the unique endemic taxa that are showcased in the lowland wet and montane regions are also under the greatest threat of extinction (Myers et al., 2000). Less than 2\% of lowland wet forests (Kathriarachchi, 2012) and less than 1\% of montane forests (Wijesundera, 2012) remain and threats to loss from human activity continue unabated. The faunal diversity that this flora supports and the flora itself are the products of 200 My of evolution and are headed towards obliteration.

\section{The cost of conservation management}

For 40 years biologists have been flagging the importance of preserving the rainforests rich in endemism and biodiversity (e.g, Crusz, 1973; Dittus, 1977b; Senanayake et al., 1977; Gunatilleke and Gunatilleke, 1983), and the same applies to rich habitats in the dry zone (Eisenberg and Lockhart, 1972; McKay, 1973). Governments decide on land use for the common good: roads, highways, schools, agricultural schemes, housing developments and commercial properties. The economic costs of such land resource allocations can be considerable, but citizens tend to expect and accept them.

Protected areas in the vast dry zone have been allotted habitat that, in large part, is unsuited for other economic purposes, (e.g., agriculture, silviculture). The cost of allocating unproductive land for conservation has been negligible. On the other hand, where natural habitat was most suitable for wildlife and conflicted with economic pressure, the habitat was simply taken over for "development" with little or no concern, or price paid, for biodiversity preservation. Either way, to date, conservation has been comparatively cost free. Safeguarding biodiversity requires a reassessment of national priorities (Miththapala, 2015), the elevation of biodiversity rich habitats to the status of an essential public resource, and science-based management policy (Fernando, 2015a). There is no monetary value that can be assigned to a national treasure, but perhaps an enlightened populace can be engaged in a greener economy (Gunatilleke, 2013, 2015).

\section{SUMMARY AND CONCLUSIONS}

- All of the earth's placental mammals originated in the Jurassic Period (125 Mya) on the supercontinent of Pangaea and underwent an evolutionary explosion in diversity in the Eocene epoch (56 Mya) in relation to major environmental changes that marked the end of the Cretaceous Period. Changes involved a collision with an asteroid at the K-Pg boundary (65.5 Mya) that wiped out the non-flying dinosaurs, extensive volcanic activity in India in the Paleocene (63 Mya), a spike in atmospheric oxygen and the proliferation of flowering plants and other biota in the Miocene. The history of Sri Lankan mammals is closely tied to that of Indian ones and was influenced by plate tectonic events that marooned India as an island plate for about 65 to 90 million years after the breakup of Pangea 180 Mya. India, with Sri Lanka in tow, reconnected with Asia only after the Paleocene (50-35 Mya). Did modern Indian mammals evolve in isolation on the Indian island plate and then disperse into Asia when the India crashed into Asia - the "out of India" hypothesis, or, are they the descendants of mammals that evolved in Asia and then spilled into India after the reconnection - the "out of Asia" hypothesis? A clarification awaits future research.

- Most endemic genera and species, which occur in the geographically restricted montane wet forests, involve small sized mammals (insectivores and rodents) with high rates of reproduction or genetic turnover. Endemic subspecies, on the other hand, occur fairly evenly distributed among other phyto-climatic zones. There is an inverse relation between body size (a proxy for mobility and genetic exchange) and the proportion of endemic taxa, suggesting enhanced gene flow among distant populations of mobile mammals within Sri Lanka. Potential faunal exchanges with southern India, by way of the Palk Strait isthmus during Pleistocene low ocean water levels, may have retarded the evolution of endemics among northern and dry zone mammals especially for the larger sized mobile ones. Bats with the highest vagility have the lowest endemicity.

- Protected areas (PAs) vary in number and size among climatic zones, being least in the mid and high montane wet zone where endemics are most frequently encountered, not only among mammals, but also among most flora and fauna, and where the majority of endangered plants and animals reside. Many endemic taxa also reside in the lowland rainforest areas with few but somewhat larger PAs than in the montane region, but these too are under rising threat of loss owed to human encroachment. The critically endangered endemic highland toque macaque (Macaca sinica opisthomelas) has no legal protection and is persecuted as a pest.

- The extensive lowland dry zone holds $85 \%$ of the area of Sri Lankan PAs and more than half of that area is arid. The productivity of these areas is poor and the carrying capacity for most mammals, especially water dependent ones, is low. Either these species occur at extremely low densities (e.g., primates) or, if they are mobile such as elephants, they encroach on human inhabited land outside the PAs in search of fodder and water. Many streams and alluvial forests that are suitable to support populations of smallsized mammals occur outside the PAs but these forests are under the greatest threat of destruction by humans.

- Newly established PAs (Kaudulla, Angammedilla, Wasgamuwa, Minneriya, Hurulu) in the moister regions of the dry zone offer suitable habitat for water-dependent mammals and offer good prospects for their preservation.

- Mammals that can adapt their diet to human produce, such as elephant, primates and wild boar, can be conspicuous 
in search of food and water near human habitation. These local concentrations, however, give a false impression of high densities of pest species nationwide, and are subject to negative publicity, persecution and inappropriate management attempts.

- Historically, the cost of wildlife management in Sri Lanka has been low because PAs were established in environments unsuited for human habitation, or, quality environments suitable for mammals were simply denied as PAs. Mammals share the fate of most other fauna and flora of Sri Lanka. If their conservation is to be taken seriously, particularly for the critically endangered taxa of the montane regions, then the cost of conserving the diversity of mammals and that of most other biota requires urgent realignment as a national priority. If this is not done the apical taxa from 200 million years of evolution will be traded for vegetable plots, tea cultivations and dairy farms in Sri Lanka's highlands. How will future generations denied this unique biological heritage judge current governance?

\section{ACKNOWLEDGEMENTS}

For research approvals and administrative support I thank Prof. S. H. P. Karunaratne, Director of the National Institute of Fundamental Studies, Ministry of Science, Technology and Research, Sri Lanka, Peter Leimgruber, Head, Conservation Ecology Center, Smithsonian Conservation Biology Institute, USA. I thank the staff of the Association for the Conservation of Primate Diversity (ACPD), Vatsala Dittus, Sunil Gunathilake, Chameera Pathirathne and Sunil Rathnayake for assuming the many responsibilities of the ACPD; it allowed me the time needed to prepare this report. I thank Channa Bambaradeniya, Victoria Buckley, John Capener, Praveen Karanth and an anonymous reviewer for constructive comments on the draft.

\section{REFERENCES}

Aitchison, J.C., Ali, J.R. and Davis, A.M. (2007). When and where did India and Asia collide? Journal of Geophysical Research 112:B05423, 1-19.

Ali, J.R. and Aitchison, J.C. (2008). Gondwana to Asia: Plate tectonics, paleogeography and the biological connectivity of the Indian sub-continent from the Middle Jurassic through latest Eocene (166-35 Ma). Science Direct Reviews 88: 145-166.

Alvarez, L.W., Alvarez, W., Asaro, F. and Michel, H.V. (1980). Extraterrestrial cause for the CretaceousTertiary extinction. Science 208: 1095-1108.

Andrews, J.R.T. (1961). A Forest Inventory of Ceylon Government Press, Sri Lanka, pp. 116.

Ashton, P.M., Gunatilleke, C.V.S., Zoyza, N., Dassanayake, M.D., Gunatilleke, I.A.U.N. and Wijesundara, S. (1997). A Field Guide to the Common Trees and Shrubs of Sri Lanka. WHT Publications (Pvt.) Ltd., Sri Lanka, pp. 431.

Bahir, M.M. and Gabadage, D.E. (2012). Taxonomy and conservation status of the freshwater crabs (Crustacea: Decapoda) in Sri Lanka. In: D.K. Weerakoon and S. Wijesundera (Eds.), The National Red List 2012 of Sri Lanka; Conservation Status of the Fauna and Flora, Ministry of Environment, Colombo, Sri Lanka, pp. 58-
64.

Bajpai, S. (2009). Biotic perspective of the Deccan volcanism and India-Asia collision: Recent advances. In: Current Trends in Science, Platinum Jubilee Special Publication, Indian Academy of Sciences, pp. 505-516.

Baker, R.J. and Bradley, R.D. (2006). Speciation in mammals and the genetic species concept. Journal of Mammalogy 87: 643-662.

Bambaradeniya, C.N.B. (2006). The Fauna of Sri Lanka: Status of Taxonomy, Research and Conservation. The World Conservation Union, Sri Lanka and Government of Sri Lanka, Colombo, pp. 308.

Barnosky, A.D., Koch, P.L., Feranec, R.S., Wing, S.L. and Shabel, A.B. (2004). Assessing the causes of late Pleistocene extinctions on the continents. Science 306: 70-75.

Bebermeier, W., Meister, J., Withanachchi, R., Middelhaufe, I. and Schütt, B. (2017). Tank cascade systems as a sustainable measure of watershed management in South Asia. Water 9: 1-16.

Benjamin, S.P., Nanayakkara, R.P. and Dayananda, S.K. (2012). The Taxonomy and conservation status of the spiders (Arachnida: Araneae) in Sri Lanka. In: D.K. Weerakoon and S. Wijesundera (Eds.), The National Red List 2012 of Sri Lanka; Conservation Status of the Fauna and Flora, Ministry of Environment, Colombo, Sri Lanka, pp. 42-57.

Berendse, F. and Scheffer, M. (2009). The angiosperm radiation revisited, an ecological explanation for Darwin's abominable mystery. Ecology Letters 12: 865-872.

Bininda-Emonds, O.R.P., Cardillo, M., Jones, K.E., MacPhee, R.D.E., Beck, R.M.D., Grenyer, R., Price, S.A., Vos, R.A., Gittleman, J.L. and Purvis, A. (2007). The delayed rise of present-day mammals. Nature 446: 507-512.

Boivin, N., Fuller, D.Q., Dennell, R., Allaby, R. and Petraglia, M.D. (2013). Human dispersal across diverse environments of Asia during the Upper Pleistocene. Quaternary International 300: 32-47.

Bobe, R. and Behrensmeyer, A.K. (2004). The expansion of grassland ecosystems in Africa in relation to mammalian evolution and the origin of the genus Homo. Palaeogeography, Palaeoclimatology, Paleoecology 207: 399-420.

Bossuyt, F., Meegaskumbura, M., Beenaerts, N., Gower, D.J., Pethiyagoda, R., Roelants, K., Mannaert, A., Wilkinson, M., Bahir, M.M., Manemandra-Arachchi, K., Ng, P.K.L., Schneider, C.J., Oommen, O.V. and Milinkovitch, M.C. (2004). Local endemism within the Western Ghats-Sri Lanka biodiversity hotspot. Science 306: 479-481.

Bowen, G.J., Clyde, W.C., Koch, P.L., Ting, S., Alroy, J., Tsubamoto, T., Wang, Y. and Wang, Y. (2002). Mammalian Dispersal at the Paleocene/Eocene Boundary. Science 295: 2062-2064.

Brandon-Jones, D., Eudey, A., Geissmann, T., Groves, C. P., Melnick, D.J., Morales, J.C., Schekelle, M. and Steward, C-B. (2004). Asian primate classification. International Journal of Primatology 25: 97-164.

Cooper, A., Turney, C., Hughen, K.A., Brook, B.W., 
McDonald, G.H. and Bradshaw, C.J.A. (2015). Abrupt warming events drove Late Pleistocene Holarctic megafaunal turnover. Science 349: 602-606.

Cooray, P.G. (1984). The Geology of Sri Lanka (Ceylon). National Museums of Sri Lanka Publication, Colombo, pp. 340 .

Cox, B.C. and Moore, P.D. (2010). Biogeography: An Ecological and Evolutionary Approach. John Wiley and Sons, pp. 496.

Crandall, K.A., Bininda-Emonds, O.R.P., Mace, G.M. and Wayne, R.K. (2000). Considering evolutionary processes in conservation biology. Trends in Ecology and Evolution 15: 290-295.

Crusz, H. (1973). Nature conservation in Sri Lanka (Ceylon). Biological Conservation 5:199-208.

Curtis, J.T. and McIntosh, R.P. (1951). An upland forest continuum in the prairie-forest border region of Wisconsin. Ecology 32: 476-496.

Darwin, C. (1859). The Origin of Species by Means of Natural Selection, John Murray, London, pp. 502.

Datta-Roy, A. and Karanth, P.K. (2009). The Out-of-India hypothesis: what do molecules suggest? Journal of Bioscience 34: 687-697.

de Silva Wijeyertne, G. (2006). Wildlife tourism's true potential. Lanka Monthly Digest March 2006:156.

de Silva Wijeyertne, G. (2008). A Photographic Guide to Mammals of Sri Lanka. New Holland Publishers (UK), Ltd., London, pp. 128.

Dela, J.D.S. (2007). Seasonal food use strategies of Semnopithecus vetulus nestor, at Panadura and Piliyanda, Sri Lanka. International Journal of Primatology 28: 607-626.

Deraniyagala, P.E.P. (1955). A new race of leaf monkey from Ceylon. Spolia Zeylanica 27: 293-294.

Deraniyagala, P.E.P. (1958). The Pleistocene of Ceylon. Ceylon National Museums Natural History Series, Government Press, Ceylon, Colombo, pp. 164.

Dissanayake, C.B. and Chandrajith, R. (1999). Sri LankaMadagascar Gondwana linkage: Evidence for a PanAfrican mineral belt. Journal of Geology 107: 223-235.

Dissanayake, R. and Oshida, T. (2012). The systematics of the dusky striped squirrel, Funambulus sublineatus (Waterhouse, 1938) (Rodentia:Sciuridae) and its relationships to Layard's squirrel,Funambulus layardi Blyth, 1949. Journal of Natural History 46: 91-116.

Dittus, W.P.J. (1977a). The ecology of a semi-evergreen forest community in Sri Lanka. Biotropica 9:268-286.

Dittus, W.P.J. (1977b). The socioecological basis for the conservation of the toque monkey (Macaca sinica) of Sri Lanka (Ceylon). In: P.H.S.H. Rainier and G.H. Bourne (Eds.), Primate Conservation, Academic Press, New York, pp. 237-265.

Dittus, W.P. J. (1985a). The influence of cyclones on the dry evergreen forest of Sri Lanka. Biotropica 17: 1-14.

Dittus, W.P.J. (1985b). The influence of leaf-monkeys on their feeding trees in a cyclone disturbed environment. Biotropica 17: 100-106.

Dittus, W.P.J. (2012). Problems with pest monkeys: myths and solutions. Loris (Journal of the Wildlife and Nature Protection Society of Sri Lanka) 26: 18-23.

Dittus, W.P.J. (2013). Subspecies of Sri Lankan mammals as units of biodiversity conservation, with special reference to the primates. Ceylon Journal of Science (Biological Sciences) 42: 1-27.

Dittus, W.P.J. and Gamage, S. (2017, report). The montane toque macaque (Macaca sinica opisthomelas). IUCN Red list conference, Singapore, November 2015.

Eisenberg, J.F. (1981). The Mammalian Radiations. The University of Chicago Press, Chicago, pp. 610.

Eisenberg, J.F. and Lockhart, M. (1972). An Ecological Reconnaissance of Wilpattu National Park, Ceylon. Smithsonian Institution Press, Washington, DC, pp. 118.

Eisenberg, J.F. and McKay, G.M. (1970). An annotated checklist of the recent mammals of Ceylon with keys to the species. Ceylon Journal of Science (Biological Sciences) 8: 69-99.

Eizirik, E., Murphy, W.J. and O'Brien, S.J. (2001). Molecular dating and biogeography of the early placental mammal radiation. Journal of Heredity 92: 212-219.

Ekanayake, D.K., Rajapakse, R.P.V.J., Dubey, J.P. and Dittus, W.P.J. (2004). Seroprevalence of Toxoplasma gondii in Wild Toque Macaques (Macaca sinica) at Polonnaruwa, Sri Lanka. Journal of Parasitology 90: 870-871.

Ekanayake, D.K., Arulkanthan, A., Horadagoda, N.U., Sanjeevanie, G.K.M., Kieft, R., Gunathilake, K.A.S. and Dittus, W.P.J. (2006). Prevalence of Cryptosporidium and other enteric parasites among wild non-human primates in Polonnaruwa, Sri Lanka. American Journal of Tropical Medicine and Hygiene 74: 322-329.

Ekanayake, D.K., Welch, R.K., Kieft, R., Hajduk, S. and Dittus, W.P.J. (2007). Transmission dynamics of Cryprosporidium infection in a natural population of non-human primates at Polonnaruwa. American Journal of Tropical Medicine and Hygiene 77:818-822.

Falkowski, P.G., Katz, M.E., Milligan, A.J., Fennel, K., Cramer, B.S., Aubry, M.-P., Berner, R.A., Novacek, M.J. and Zapol, W.M. (2005). The rise of oxygen over the past 205 million years and the evolution of large placental mammals. Science 205: 2202-2204.

FAO. (2005). Global Forest Resources Assessment, Country Reports, Sri Lanka. FRA2005/123, Forestry Department, Food and Agriculture Organization of the United Nations, Rome, pp. 1-45.

FAO. (2010). Global Forest Resources Assessment, Country Reports, Sri Lanka. FRA2010/197, Forestry Department, Food and Agriculture Organization of the United Nations, Rome, pp. 1-55.

Fernando, P., Pfrender, M.E., Encalada, S.E. and Lande, R. (2000). Mitochondrial DNA variation, phylogeography and population structure of the Asian elephant. Heredity 84: $362-372$.

Fernando, P. (2015a). Managing elephants in Sri Lanka: Where we are and where we need to be. Ceylon Journal of Science (Biological Sciences) 44: 1-11.

Fernando, P. (2015b). The starving elephants of Udawalawe. http://www.sanctuaryasia.com/magazines/ conservation/9933-the-starving-elephants-ofudawalawe.html>.

Fernando, P., Wickramanayake, E.D., Weerakoon, D., 
Jayasinghe, L.K.A., Gunawardene, M.D. and Janaka, H.K. (2005). Perceptions and patterns in humanelephant conflict in old and new settlements in Sri Lanka: insights for mitigation and management. . Biodiversity Conservation 14: 2465-2481.

Fernando, P., Wickramanayake, E.D., Janaka, H.K., Jyasinghe, L.K.A., Gunawarndena, M., Kotagama, S.W., Weerakoon, D. and Pastorini, J. (2008). Ranging behavior of the Asian elephant in Sri Lanka. Zeitschrift für Säugetierkunde 73: 2-13.

Fernando, P., Leimgruber, P., Prasad, T. and Pastorini, J. (2012). Problem-elephant translocation: Translocating the problem and the elephant. PLoS ONE 7: 4-9.

Fernando, S.N.U. (1968). The Natural Vegetation of Ceylon. Lake House, Colombo, pp. 85.

Fleischer, R.C., Perry, E.A., Muralidharan, K., Stevens, E.S. and Wemmer, C. M. (2001). Phylogeography of the Asian elephant (Elephas maximus) based on mitochondrial DNA. Evolution 55: 1882-1892.

Fleming, K., Johnson, P., Zwartz, D., Yokomaya, Y., Lambeck, K. and Chappell, J. (1998). Refining the eustatic sea-level curve since the Last Glacial Maximum using far- and intermediate-field sites. Earth and Planetary Science Letters 163: 327-342.

Gamage, S.N., Liyanage, W., Weerakoon, D. and Gunwardena, A. (2009). Habitat quality and availability of the Sri Lanka Red Slender Loris Loris tardigradus Mammalia: Primates: Lorisidae) in the Kottawa Arboretum. Journal Threatened Taxa 1: 65-71.

Gamage, S.N., Reardon, J.T., Padmalal, K.U.K.G. and Kotagama, S.W. (2010). First physical examination of the Horton Plains Slender Loris Loris tardigradus nycticeboides, in 72 years. Primate Conservation 25: 57-60.

Gamage, S.N., Padmalal, K.U.K.G. and Kotagama, S.W. (2014). Montane slender loris (Loris tardigradus nycticeboides) is a critically endangered primate that needs more conservation attention. Wildlanka (Journal of the Department of Wildlife Conservation. Sri Lanka) 2: 77-83.

Gamage, S., Groves, C.P., Manikar, F.M.M., Turner, C.S., Padmalal, K.U.K.G. and Kotagama, S.W. (2017). The taxonomy, distribution, and conservation status of the Slender Loris (Primates, Lorisidae: Loris) in Sri Lanka. Primate Conservation 31 (online).

Gaussen, H., Viart, M., Legris, P. and Labroue, L. (1964). International map of the vegetation of Ceylon. Ceylon Survey Department, Colombo.

Geekiyanage, N. and Pushpakumara, D.K.N.G. (2013). Ecology of ancient tank cascade systems in island Sri Lanka. Journal of Marine and Island Cultures 2: 93101.

Goonatilake, S. de A. (2012). The taxonomy and conservation status of the freshwater fishes in Sri Lanka. In: D.K. Weerakoon and S. Wijesundara (Eds.), The National Red List 2012 of Sri Lanka; Conservation Status of the Fauna and Flora. Ministry of Environment, Colombo, Sri Lanka, pp. 77-87.

GOSL [Government of Sri Lanka]. (2000). Forest cover mapping 2000. Forest Inventory Division, Forest Department, Colombo, Sri Lanka.
Green, M.J.B. and Gunawardena, E.R.N. (1997). Designing an optimum protected areas system for Sri Lanka's natural forests. Department of Forestry, Vol. 1, Ministry of Lands, Agriculture and Forestry [Government of Sri Lanka], Colombo, pp. 1-204.

Groves, C. (2001) Primate Taxonomy. Smithsonian Institution, Washington, D. C. pp. 350.

Groves, C., Rajapaksha, C. and Manemandra-Arachchi, K. (2009). The taxonomy of the golden palm civet of Sri Lanka. Zoological Journal of the Linnean Society 155:238-251.

Groves, C. and Meijaard, E. (2005). Interspecific variation in Moschiola, the Indian chevrotain. The Raffles Bulletin of Zoology Supplement 12: 413-421.

Gunatilleke, I.A.U.N. and Gunatilleke, C.V.S. (1983). Conservation of natural forests in Sri Lanka. Sri Lanka Forester 16: 39-56.

Gunatilleke, C.V.S. and Ashton, P.S. (1987). New light on the plant geography of Ceylon II. The ecological biogeography of the lowland endemic tree flora. Journal of Biogeography 14: 295-327.Gunatilleke, C.V.S. (2013). Towards a green economy in Sri Lanka: a forestry perspective. Journal of the National Science Foundation of Sri Lanka 41: 271-272.

Gunatilleke, C.V.S. (2015). Forest sector in a green economy: a paradigm shift in global trends and national planning in Sri Lanka. Journal of the National Science Foundation of Sri Lanka 43: 101-109.

Gunatilleke, I.A.U.N. and Gunatilleke, C.V.S. (1991). Threatened Woody Endemics of the Wet Lowlands of Sri Lanka and their Conservation. Biological Conservation 55: 17-36.

Gunatilleke, C.V.S., Gunatilleke, I.A.U.N., Ethugala, A.U.K. and Esufali, E. (2004). Ecology of Sinharaja rain forest and the forest dynamics plot in Sri Lanka's Natural World Heritage Site. WHT Publications (Pvt.) Ltd., Sri Lanka.

Gunatilleke, C.V.S., Gunatilleke, I.A.U.N., Esufali, E., Harms, K.E., Ashton, P.M.S., Burslem, D.F.R.P. and Ashton, P.S. (2006). Species-habitat associations in a Sri Lankan dipterocarp forest. Journal of Tropical Ecology 22: 371-384.

Halliday, J.D. and Goswami, A. (2016). Eutherian morphological disparity across the end-Cretaceous mass extinction. Biological Journal of the Linnean Society 118: 152-168.

Halliday, T.J.D., Upchurch, P. and Goswami, A. (2015). Resolving the relationships of Paleocene placental mammals. Biological Reviews of the Cambridge Philosophical Society. DOI 10.1111/brv.12242

Heaney, L.R. (1986). Biogeography of mammals in SE Asia: Estimates of rates of colonization, extinction and speciation. Biological Journal of the Linnean Society 28: $127-165$.

Hey, J., Waples, R.S., Arnold, M.L., Butlin, R.K. and Harrison, R.G. (2003). Understanding and confronting species uncertainty in biology and conservation. Trends in Ecology and Evolution 18: 597-603.

Hill, O.W.C. (1942). The highland macaque of Ceylon. Journal of the Bombay Natural History Society 43: 402-406. 
Hladik, M.C. and Hladik, A. (1972). Disponsibilités alimentaires et domaines vitaux des Primates à Ceylan. La Terre et la Vie 26:149-215.

Hoelzer, G.A., Dittus, W.P.J., Ashley, M.V. and Melnick, D.J. (1994). The local distribution of highly divergent mitochondrial DNA haplotypes in toque macaques Macaca sinica at Polonnaruwa, Sri Lanka. Molecular Ecology 3:451-458.

von Humboldt, A. (1805). Essai sur la Geographie des Plantes; Accompagne d'un Tableau Physique des Régions Equinoxiales. Levrault, Paris.

Ishwaran, N. (1981). Comparative study on elephant populations in Gal Oya Sri Lanka. Biological Conservation 21:303-313.

Ishwaran, N. (1983). Elephant and woody-plant relationships in Gal Oya, Sri Lanka. Biological Conservation 26:255-270.

IUCN. (2017). The IUCN Red List of Threatened Species. 2017-2.

Jayasekara, P., Weerasinghe, U.R., Wijesundara, S. and Takatsuki, S. (2007). Identifying diurnal and nocturnal frugivores in the terrestrial and arboreal layers of a tropical rain forest in Sri Lanka. Ecotropica 13:7-15.

Jaysuriya, M.A.H., Kitchener, D. and Biradar, C.M. (2006). Portfolio of Strategic Conservation Sites/ Protected Area GAP Analysis in Sri Lanka. Ministry of Environment and Natural Resources, EML Consultants, Colombo, pp. 1-284.

Jayewardene, J. (1994). The Elephant in Sri Lanka. Wildlife Heritage Trust, Colombo, Sri Lanka, pp. 124.

Ji, Q., Luo, Z.-X., Yuan, C.-X., Wible, J.R., Zhang, J.-P. and Georgi, J.A. (2002). The earliest known eutherian mammal. Nature 416: 816-822.

Karanth, P.K. (2006). Out-of-India Gondwanan origin of some tropical Asian biota. Current Science 90:789-792.

Karanth, P.K. (2010). Molecular systematics and conservation of the langurs and leaf monkeys of South Asia. Journal of Genetics 89: 393-399.

Kathriarachchi, H.S. (2012). Present status of lowland wet zone flora of Sri Lanka. In: D. Weerakoon and S. Wijesundara (Eds), The National Red List 2012 of Sri Lanka; Conservation Status of the Fauna and Flora Ministry of Environment, Colombo, Sri Lanka, pp. $175-180$

Katupotha, J.(1995). Evolution and Geological Significance of late Pleistocene Fossil Shell Beds of the Southern Coastal Zone of Sri Lanka. Natural Resources, Energy and Science Authority of Sri Lanka, Colombo, pp. 63.

Katupotha, J. (2013). Palaeoclimate change during Glacial Periods: Evidence from Sri Lanka. Journal of Tropical Forestry and Environment 3: 42-54.

Kennedy, K.A.R., Deraniyagala, S.U., Roertgen, J.C. and Disotell, T.R. (1987). Upper Pleistocene fossil hominids from Sri Lanka. American Journal of Physical Anthropology 72: 441-461.

Kittle, A.M. and Watson, A.C. (2003). Leopard poaching in Sri Lanka. Loris (Journal of the Wildlife and Nature Protection Society of Sri Lanka) 23: 42-49.

Kittle, A.M. and Watson, A.C. (2008). Panthera pardus ssp kotiya. The IUCN Red List of Threatened Species 2008:e.15959A5334064.
Kittle, A.M., Watson, A.C., Cushman, S.A. and Macdonald, D.W. (2017). Forest cover and level of protection influence the island-wide distribution of an apex carnivore and umbrella species, the Sri Lankan leopard (Panthera pardus kotiya). Biodiversity and Conservation [online DOI, 10.1007/s10531-017-14318], pp. 1-29.

Kittle,A.M., Watson, A.C., Kumara, C.P.H.S., Sandanayake, K.S.D., Sanjeewani, N.H.K. and Fernando, S.T. (2014). Notes on the diet and habitat selection of the Sri Lankan leopard Panthera pardus kotiya (Mammalia: Felidae) in the central highlands of Sri Lanka. Journal of Threatened Taxa 6: 6214-6221.

Koelmeyer, K.O. (1958). Climatic classification and the distribution of vegetation in Ceylon. Ceylon Forester 3: 265-293.

Kotagama, S.W. (1989). Map of the Avifauna Zones of Sri Lanka, Strategy for the Preparation of a Biological Diversity Action Plan for Sri Lanka. Ministry of Transport, Environment and Women's Affairs, Colombo, pp. 1-88.

Krause, D.W., Prasad, G.V.R., von Koenigswald, W., Sahni, A. and Grine, F.E. (1997). Cosmopolitanism among Gondwanan Late Cretaceous mammals. Nature 390: 504-507.

Kudavidanage, E.P. and Lekamge, D. (2012). A provisional checklist of dung beetles (Coleoptera: Scarabaeidae) in Sri Lanka. In: D. K. Weerakoon and S. Wijesundera (Eds.), The National Red List 2012 of Sri Lanka; Conservation Status of the Fauna and Flora, Ministry of Environment, Colombo, Sri Lanka, pp. 438-444.

Kurt, F., Hartl, G.B. and Tiedemann, R. (1995). Tuskless bulls in Asian elephant Elephas maximus. History and population genetics of a man-made phenomenon. Acta Theriologica, Supplement 3: 125-143.

Legg, C. and Jewell, N. (1995). A 1:50,000 Forest Map of Sri Lanka: the Basis for a National Forest Geographic Information System. Forestry Information Services, The Sri Lanka Forest Department, Battaramulla, Sri Lanka.

MacArthur, R.H. and Wilson, E.O. (1967). Island Biogeography. Princeton University Press, Princeton, NJ, pp. 215.

Manamendra-Arachchi, K. and Meegaskumbura, M. (2012). The taxonomy and conservation status of amphibians in Sri Lanka. In: D.K. Weerakoon and S. Wijesundera (Eds.), The National Red List 2012 of Sri Lanka; Conservation Status of the Fauna and Flora, Ministry of Environment, Colombo, Sri Lanka, Pp. 8898.

Manamendra-Arachchi, K., Pethiyagoda, R., Dissanayake, R. and Meegaskumbura, M. (2005). A second big cat from the later Quaternary of Sri Lanka. The Raffles Bulletin of Zoology 12: 423-434.

Martin, R.D. (2003). Combing the primate record. Nature 422: 388-391.

Masters, J.C., Anthony, N.M., deWit, M.J. and Mitchell, A. (2005). Reconstructing the evolutionary history of the Lorisidae using morphological, molecular, and geological data. American Journal of Physical Anthropology 127: 465-480. 
Masters, J.C., De Wit, M.J. and Asher, R.J. (2006). Reconciling the origins of Africa, India and Madagascar with vertebrate dispersal scenarios. Folia Primatologica 77: 399-418.

Mattsson, E., Persson, M.U., Ostwald, M. and Nissanka, S.P. (2012). REDD plus readiness implications for Sri Lanka in terms of reducing deforestation. Journal of Environmental Management 100: 29-40.

McKay, G.M. (1973). Behavior and Ecology of the Asiatic Elephant in Southeastern Ceylon. Smithsonian Institution Press, Washington, DC, pp. 113.

McKay, G.M. (1984). Ecology and biogeography of mammals. In: C.H. Fernando (Ed.), Ecology and Biogeography of Sri Lanka. Dr W. Junk Publishers, The Hague, pp. 413-429.

McKay, G.M. and Eisenberg, J.F. (1974). Movement patterns and habitat utilization of ungulates in Ceylon. In: V. Geist and F. Walther (Ed.), Behavior of ungulates and its relation to management $\mathrm{I}$. U. C. N. Publication New Series 24, Morges pp. 708-721.

Meegaskumbura, S., Meegaskumbura, M., Pethiyagoda, R., Manemandra-Arachchi, K. and Schneider, C.J. (2007). Crocidura hikmiya, a new shrew (Mammalia: Soricomorpha: Soricidae) from Sri Lanka. Zootaxa 1665:19-30.

Meegaskumbura, S. and Schneider, C.J. (2008). A taxonomic evaluation of the shrew Suncus montanus (Soricidae: Crocidurinae) of Sri Lanka and India. Ceylon Journal of Science (Biological Sciences) 37: 129-136.

Mellars, P., Gori, K.C., Martin, C., Soares, P.A. and Richards, M.B. (2013). Genetic and archaeological perspectives on the initial modern human colonization of southern Asia. Proceedings of the National Academy of Sciences, USA 110: 10699-10704.

Miller, K.G., Browning, J.V., Aubry, M.-P., Wade, B.S., Katz, M.E., Kulpecz, A.A. and Wright, J.D. (2008). Eocene-Oligocene global climate and sea-level changes: St. Stephens Quarry, Alabama. Geological Society of America Bulletin 120: 34-53.

Milne, G.A., Long, A.J. and Bassett, S.E. (2005). Modelling Holocene relative sea-level observations from the Caribbean and South America. Quaternary Science Reviews 24:1183-1202.

Miththapala, S. (2006). The ecology of the wild cats of Sri Lanka. In: C.N.B. Bambaradeniya (Ed.), Fauna of Sri Lanka: Status of Taxonomy, Research and Conservation IUCN, Colombo, Sri Lanka, pp. 235-256.

Miththapala, S. (2015). Conservation revisited. Ceylon Journal of Science (Biological Sciences) 44:1-26.

Miththapala, S., Seidensticker, J. and O`Brien, S.J. (1996). Phylogeographic subspecies recognition in leopards (Panthera pardus): Molecular genetic variation. Conservation Biology 10: 1115-1132.

Miththapala, S., Seidensticker, J., Phillips, L.G., Goodrowe, K.L., Fernando, S.B.U., Forman, L. and O'Brien, S.J. (1991). Genetic variation on Sri Lankan leopards. Zoo Biology 10: 139-146.

Mittermeier, R.A., Valladares-Padua, C., Rylands, A.B., Eudey, A.A., Butynski, T.M., Ganzhorn, J.U., Kormos, R., Aguiar, J.M. and Walker, S. (2006). Primates in
Peril: The World's 25 Most Endangered Primates, 2004-2006. Primate Conservation 20: 1-28.

MOE. (2012). The National Red List 2012 of Sri Lanka; Conservation Status of the Fauna and Flora. Ministry of Environment Colombo, Sri Lanka, pp. 476.

Molur S., Brandon-Jones, D., Dittus, W.P.J., Eudey, A., Kumar, A., Singh, M., Feeroz, M.M., Chalise, M., Priya, P. and Walker, S. (2003). Status of South Asian Primates: Conservation Assessment and Management Plan (C.A.M.P.) Workshop Report, 2003. Zoo Outreach Organization / CBSG-South Asia: Coimbatore, India, pp. 426.

Moritz, C. (1994). Defining 'Evolutionary Significant Units' for conservation. Trends in Ecology and Evolution 9: 373-375.

Moritz, C. (2002). Strategies to protect biological diversity and the evolutionary processes that sustain it. Systematic Biology 51: 238-254.

Mueller-Dombois, D. (1972). Crown distortion and elephant distribution in the woody vegetation of Ruhunu National Park, Ceylon. Ecology 53: 208-226.

Mueller-Dombois, D. and Sirisena, V.A. (1967). Climate Map of Ceylon. Ceylon Survey Department, Colombo, Sri Lanka.

Muckenhirn, N.A. and Eisenberg, J.F. (1973). Home ranges and predation of the Ceylon leopard. In: R.L. Eaton (Ed.), The World's Cats, Volume 1, Ecology and Conservation. World Wildlife Safari, Winston, Oregon, pp. 142-175.

Murphy, W.J., Eizirik, E., O’Brian, S.J., Madsen, O., Scally, M., Douady, C.J., Teeling, E., Ryder, O.A., Stanhope, M.J., de Jong, W.W. and Springer, M.S. (2001). Resolution of the Early Placental Mammal Radiation Using Bayesian Phylogenetics. Science 294: 2348-2351.

Murphy, W.J., Eizirik, E., Johnson, W.E., Zhang, Y.P., Ryder, O.A. and O'Brien, S.J. (2001a). Molecular phylogenetics and the origins of placental mammals. Nature 409: 614-618.

Murphy, W.J., Eizirik, E., O’Brian, S.J., Madsen, O., Scally, M., Douady, C.J., Teeling, E., Ryder, O.A., Stanhope, M.J., de Jong, W.W. and Springer, M.S. (2001b). Resolution of the Early Placental Mammal Radiation Using Bayesian Phylogenetics. Science 294: 2348-2351.

Myers, N., Mittermeier, R.A., Mittermeier, C.G., Fonseka da, G.A.B. and Kent, J. (2000). Biodiversity hotspots for conservation priorities. Nature 403: 853-858.

Nekaris, A.K.I. and Jayewardene, J. (2004). Survey of the slender loris (Primates, Lorisidae Gray, 1821: Loris tardigradus Linnaeus, 1758 and Loris lydekkerianus Cabrera, 1908) in Sri Lanka. Journal of Zoology 262: 327-338.

Nekaris, A.K.I. and de Silva Wijeyeratne, G. (2009). The Primates of Sri Lanka. Sri Lanka Tourism Promotion Bureau, Colombo, pp. 152.

Nyakatura, K. and Bininda-Emonds, O.R.P. (2012). Updating the evolutionary history of Carnivora (Mammalia): a new species-level supertree complete with divergence time estimates. Bio Med Central Biology 10: 12. 
O’Brien, S.J. and Mayr, E. (1991). Bureaucratic Mischief: Recognizing Endangered Species and Subspecies. Science 251:1187-1188.

O'Leary, M.A., Bloch, J.I., Flynn, J.J., Gaudin, T.J., Giallombardo, A., Giannini, N.P., Goldberg, S.L., Kraatz, B.P., Luo, Z.-X., Meng, J., Ni, X., Novacek, M.J., Perini, F.A., Randall, Z.S., Rougier, G.W., Silcox, M.T., Simmons, N.B., Spaulding, M., Velazco, P.M., Weksler, M., Wibe, J.R. and Cirranello, A.L. (2013). The placental mammal ancestor and the Post-K-Pg radiation of placentals. Science 339:662-667.

Osborne, C.P. (2008). Atmosphere, ecology and evolution: What drove the Miocene expansion of $\mathrm{C} 4$ grasslands? Journal of Ecology 96:35-45.

Pastorini, J., Nishantha, H.G., Janaka, H.K. and Fernando, P. (2010). Water body use by Asian elephants in Southern Sri Lanka. Tropical Conservation Science 3:412-422

Pastorini, J., Janaka, H.K., Nishantha, H.G., Prasad, T., Leimgruber, P. and Fernando, P. (2013). Preliminary study on the impacts of changing shifting cultivation practices on dry season forage for Asian elephants in Sri Lanka. Tropical Conservation Science 6:770-780

Perera, A.D. (2005). Spatial heterogeneity of the soil seed bank in the tropical semideciduous forest at Wasgomuwa National Park, Sri Lanka. Tropical Ecology 46:1-10.

Perera, A.D. (2012). Present status of Dry-zone flora in Sri Lanka. In: D. Weerakoon and S. Wijesundara (Eds.), The National Red List 2012 of Sri Lanka; Conservation Status of the Fauna and Flora. Ministry of Environment, Colombo, Sri Lanka, pp. 165-174.

Perera, N., Kourampas, N., Simpson, I.A., Deraniyagala, S.U., Bulbeck, D., Kamminga, J., Perera, J., Fuller, D.Q., Szabó, K. and Oliveira, N.V. (2011). People of the ancient rainforest: Late Pleistocene foragers at the Batadomba-lenarockshelter, Sri Lanka. Journal of Human Evolution 61:254-269.

Perera, S.M.J. (2008). A review of the distribution of grey slender loris (Loris lydekkerianus) in Sri Lanka. Primate Conservation 23:89-96.

Perera, S.M., Rodrigo, R.K., Perera, N.W.P., Samarawickrema, P.V.A., Asela, C.M.D., Chandraminal, D. and Perera, D.R. (2009). The extension of the range of the grey slender loris (Loris lydekkerianus) to the south-east of Sri Lanka. Loris 25:5-7.

Pethiyagoda, R. (2012a). Horton Plains: Sri Lanka's Cloud Forest National Park. WHT Publications, Colombo, pp. 320

Pethiyagoda, R. (2012b). Biodiversity conservation in Sri Lanka's novel ecosystems. Ceylon Journal of Science (Biological Sciences) 41:1-10.

Pethiyagoda, R., DeSilva, M. and Hapuarachchi, N.C. (2012). Sri Lankan Primates: an Enthusiasts' Guide. Gunaratne Offset (Pvt) Ltd., Colombo, pp. 126

Phillips, W.W.A. (1935). Manual of the Mammals of Ceylon, Ceylon Journal of Science. Dulau and Company, London. pp. 373.

Phillips, W.W.A. (1980). Manual of the Mammals of Sri Lanka, $2^{\text {nd }}$ revised edition, Part I, II and III. Wildlife and Nature Protection Society, Colombo. pp. 399.

Pozzi, L., Nekaris, A.K.I., Perkin, A., Bearder, S.K.,
Pimley, E.R., Schulze, H., Streicher, U., Nadler, T., Kitchener, A., Zischler, H., Zinner, D. and Roos, C. (2015). Remarkable ancient divergences amongst neglected lorisiform primates. Zoological Journal of the Linnean Society 175:661-674.

Ranawana, K.B. and Priyadarshana, T.G.M. (2012). The taxonomy and conservation status of the land snails in Sri Lanka. In: D.K. Weerakoon and S. Wijesundera (Eds.), The National Red List 2012 of Sri Lanka; Conservation Status of the Fauna and Flora, Ministry of Environment, Colombo, Sri Lanka, pp. 65-76.

Ratnaweera, P.B. and Wijesinghe, M.R. (2009). Effect of food quality and availability on rainforest rodents of Sri Lanka. Journal of Threatened Taxa 1:581-588.

Ratnayeke, S.M., Van Manen, F.T. and Padmalal, K.U.K.G. (2007). Home ranges and habitat use of sloth bears Melursus ursinus inornatus in Wasgomuwa National Park, Sri Lanka. Wildlife Biology 13:272-284.

Ratnayeke, S.M., Van Manen, F.T., Peiris, R. and Pragash, V.,S.J. (2014). Challenges of large carnivore conservation: sloth bear attacks in Sri Lanka. Human Ecology 42:467-479.

Richard, A.F., Goldstein, S.J. and Dewar, R.E. (1989). Weed macaques: the evolutionary implications of macaque feeding ecology. International Journal of Primatology 10:569-594.

Riddle, B.R., Dawson, M.N., Hadley, E.A., Mantooth, S.J. and Yoder, A.D. (2008). The role of molecular genetics in sculpting the future of integrative biogeography. Progress in Physical Geography 32:173-202.

Ripley, S. and Schikele, E. (1970). Dehydration and water needs in Ceylon primates. (Unpublished report)

Roberts, P., Delson, E., Miracle, P., Ditchfield, P., Roberts, R.G., Jacobs, Z., Blinkhorn, J., Ciochon, R.L., Fleagle, J.G., Frost, S.R., Gilbert, C.C., Gunnell, G.F., Harrison, T., Korisettar, R. and Petraglia, M.D. (2014). Continuity of mammalian fauna over the last 200,000 y in the Indian subcontinent. Proceedings of the National Academy of Science (USA) 111:5848-5853.

Roberts, P., Perera, N., Wedage, O., Deraniyagala, S., Perera, J., Eregama, S., Gledhill, A., Petragila, M.D. and Lee-Thorp, J.A. (2015). Direct evidence for human reliance on rainforest resources in late Pleistocene Sri Lanka. Science 347:1246-1249.

Rohling, E.J., Fenton, M.J.J.F., Bertrand, P., Ganssen, G. and Caulet, J.P. (1998). Magnitudes of sea-level lowstand of the past 500,000 years. Nature 394:162165.

Rose, K.D. and Archibald, D.J. (2005). The Rise of Placental Mammals: Origins and Relationships of the Major Extant Clades. The Johns Hopkins University Press, Baltimore and London. pp. 280.

Rose, K.D., Holbrook, L.T., Rana, R.S., Kumar, K., Jones, K.E., Ahrens, H.E., Missiaen, P., Sahni, A. and Smith, T. (2014). Early Eocene fossils suggest that the mammalian order Perissodactyla originated in India. Nature Communications 5: 5570 (2014), DOI: 10.1038/ ncomms6570.

Rudran, R. (2007). A survey of Sri Lanka's endangered and endemic western Purple-faced Langur (Trachypithecus vetulus nestor). Primate Conservation 22:139-144. 
Rudran, R., Dayananda, S.K., Jayamanne, D.D. and Sirimanne, D.G.R. (2013). Food habits and habitat use patterns of Sri Lanka's Western Purple-faced Langur. Primate Conservation 27:99-108.

Ryder, O.A. (1986). Species conservation and systematics: the dilemma of subspecies. Trends in Ecology and Evolution 1:9-10.

Santiapillai, A. and Santiapillai, C. (1990). Status, distribution and conservation of the sloth bear (Melursus ursinus) in Sri Lanka. Tiger Paper 1:13-15.

Santiapillai, C. and Wijeyamohan, S. (2003). The impact of civil war on wildlife in Sri Lanka. Current Science 84:1182-1183.

Santiapillai, C., Silva, A., Karyawasam, C., Esufali, S., Jayanththi, S., Basnayake, M., Unatenne, V. and Wijeyamohan, S. (2002). Trade in Asian elephant ivory in Sri Lanka. Oryx 33:176-180.

Schlanger, S.O. and Silva, P.I. (1986). Oligocene sea-level falls recorded in mid-Pacific atoll and archipelagic apron settings. Geology 14:392-295.

Schulte, P., Alegret, L., Arenillas, I., Arz, J.A., Barton, P.J., Bown, P.R.,J.,B.T., Christeson, G.L., Claeys, P., Cockell, C.S., Collins, G.S. and Deutsch, A. (2010). The Chicxulub asteroid impact and mass extinction at the Cretaceous-Paleogene boundary. Science 327:12141218.

Seiffert, E.R., Simons, E.L. and Attia, Y. (2003). Fossil evidence for an ancient divergence of lorises and galagos. Nature 422:421-424.

Senanayake, R.F., Soule, M.E. and Senner, J.W. (1977). Habitat values and endemicity in the vanishing rain forests of Sri Lanka. Nature 265:351-354.

Seneviratne, A. (1987). The Hydraulic Civilization of the Ancient Rajarata in Sri Lanka. IWMI (International Water Management Institute), Colombo, Sri Lanka, pp. 107.

Shotake, T., Nozawa, K. and Santiapilai, C. (1991). Genetic variability within and between the troops of toque macaques, Macaca sinica, in Sri Lanka. Primates 32:283-299.

Sims, G.E., Jun, S.-R., Wu, A.G. and Kim, S.-H. (2009). Whole-genome phylogeny of mammals: Evolutionary information in genic and nongenic regions. Proceedings of the National Academy of Sciences of the United States of America 106:17077-17073.

Solé, F. and Smith, T. (2013). Dispersals of placental carnivorous mammals (Carnivoramorpha, Oxyaenodonta \& Hyaenodontida) near the PaleoceneEocene boundary: a climatic and almost worldwide story. Geologica Belgica 16:254-261.

Sumanarathna, A.R., Katupotha, J., Abeywardhana, K. and Madurapperuma, B. (2017). Extrinction of Quaternary mammalian habitats of megafauna in Sabaragamu Basin, Sri Lanka. Journal of Eco Astronomy 01:16-31.

Traver, J.E., dos Reis, M., Mirarab, S., Moran, R.J., Parker, S., O’Reilly, J.E., King, B.L., O’Connell, M.J., Asher, R.J., Warnow, T., Peterson, K.J., Donoghue, P.C.J. and Pisani, D. (2016). The Interrelationships of Placental Mammals and the Limits of Phylogenetic Inference. Genome Biology and Evolution. DOI:10.1093/gbe/ evv261
Tavaré, S., Marshall, C.R., Will, O., Soligo, C. and Martin, R.D. (2002). Using the fossil record to estimate the age of the last common ancestor of extant primates. Nature 416:726-729.

Vancuylenberg, B.W.B. (1977). Feeding behaviour of the Asiatic elephant in South-East Sri Lanka in relation to conservation. Biological Conservation 12:33-54.

Vislobokova, I.A. (2008). Main stages in evolution of Artiodactyla communities from the Pliocene-Early Middle Pleistocene of northern Eurasia: Part 2. Paleontological Journal 42:414-424.

Vogler, A.P. and DeSalle, R. (1994). Diagnosing units of conservation management. Conservation Biology 8:354-363.

Wachtler, M. (2016). A short history about the evolution of gymnosperms. In: D. Museum (Ed.), Fossil Triassic plants from Europe and their evolution. Dolomythos Museum - Oregon Institute of Geological Research, Innichen, Italy, pp. 3-16.

Wallace, A.R. (1876). The Geographical Distribution of Animals. Macmillan, London, pp. 612.

Weerakoon, D. (2012a). The taxonomy and conservation status of mammals in Sri Lanka. In: D. Weerakoon and S. Wijesundara (Ed.), The National Red List 2012 of Sri Lanka; Conservation Status of the Fauna and Flora Ministry of Environment, Colombo, Sri Lanka, pp. 134-144.

Weerakoon, D. (2012b). Analysis of faunal groups. In: D. K. Weerakoon and S. Wijesundera (Eds.), The National Red List 2012 of Sri Lanka; Conservation Status of the Fauna and Flora, Ministry of Environment, Colombo, Sri Lanka, pp. 145-147.

Weerakoon, D.K. and Goonatilake, W.L.D.P.T.S.D.A. (2006). Taxonomic status of mammals of Sri Lanka. In: C.N.B. Bambaradeniya (Ed.), The Fauna of Sri Lanka IUCN, Colombo, pp. 216-231.

Weerakoon, D. and Gunawardena, K. (2012). The Taxonomy and Conservation Status of Birds in Sri Lanka. In: D.K. Weerakoon and S. Wijesundera (Eds.), The National Red List 2012 of Sri Lanka; Conservation Status of the Fauna and Flora, Ministry of Environment, Colombo, Sri Lanka, pp. 114-133.

Wegener, A. (1915). Die Entstehung der Kontinente und Ozeane. Friedrich Vieweg \& Sohn Akt. Ges., Braunschweig, pp. 381.

White, T.D., Asfaw, B., Beyene, Y., Maile-Selassie, Y., Lovejoy, O.C., Suwa, G. and Wolde-Gabriel, G. (2009). Ardipithecus ramidus and the paleobiology of early homninids. Science 326:64-86.

Wickramasinghe, M.L.J. (2012). The taxonomy and conservation status of the reptile fauna in Sri Lanka. In: D.K. Weerakoon and S. Wijesundera (Eds.), The National Red List 2012 of Sri Lanka; Conservation Status of the Fauna and Flora, Ministry of Environment, Colombo, Sri Lanka, pp. 99-113.

Wijesinghe, L.C.A.D., Gunatilleke, I.A.U.N., Jayawardene, S.D.G., Kotagama, S.W. and Gunatilleke, C.V.S. (1993). Biological Conservation in Sri Lanka: A National Status Report. IUCN World Conservation Union, Colombo, Sri Lanka, pp. 100.

Wijesinghe, M.R. (2006). Ecological traits of endemic 
small mammals in rainforests of Sri Lanka, and their implications for conservation. In: C.N.B. Bambaradeniya (Ed). The Fauna of Sri Lanka. IUCN, Colombo, Sri Lanka. Pp. 232-234.

Wijesinghe, M.R. (2012). Predicting effects of rainforest fragmentation from live trapping studies of small mammals in Sri Lanka. Journal of Threatened Taxa 4:2629-2636.

Wijesinghe, M.R. and Brooke, M.d.L. (2005). Impact of habitat disturbance on the distribution of endemic species of small mammals and birds in a tropical rain forest in Sri Lanka. Journal of Tropical Ecology 21:661-668.

Wijesundara, S. (2012). Present status of montane forests in Sri Lanka. In: D. Weerakoon and S. Wijesundara (Eds.), The National Red List 2012 of Sri Lanka; Conservation Status of the Fauna and Flora Ministry of Environment, Colombo, Sri Lanka, pp. 181-185.

Wijesundara, S., Kathriarachchi, H.S., Ranasinghe, S.W. and Hapuarachchi, N.C. (2012). Analysis of seed plants of Sri Lanka. In: D. Weerakoon and S. Wijesundara (Ed.), The National Red List 2012 of Sri Lanka; Conservation Status of the Fauna and Flora Ministry of Environment, Colombo, Sri Lanka, pp. 338-345.

Wikramanayake, E.D. and Gunatilleke, S. (2002a). Sri Lanka dry-zone evergreen forests. In: E. D. Wikramanayake, E. Dinerstein, C.J. Loucks, D.M. Olson, J. Morrison, J. Lamoreux, M. McKnight and P. Hedao (Eds.), Terrestrial Ecoregions of the Indo-Pacific Island Press, Washington, DC, pp. 296-298.
Wikramanayake, E.D. and Gunatilleke, S. (2002b). Sri Lanka lowland rainforests. In: E.D. Wikramanayake, E. Dinerstein, C. Loucks, D.M. Olson, J. Morrison, J. Lamoreux, M. McKnight and P. Hedao (Eds.), Terrestrial Ecoregions of the Indo-Pacific Island Press, Washington, DC, pp. 287-290.

Wikramanayake, E.D. and Gunatilleke, S. (2002c). Sri Lanka montane rain forests. In: E.D. Wikramanayake, E. Dinerstein, C. Loucks, D.M. Olson, J. Morrison, J. Lamoreux, M. McKnight and P. Hedao (Eds.), Terrestrial Ecoregions of the Indo-Pacific Island Press, Washington, DC, pp. 290-293.

Woodburne, M.O. and Springer, R.T.H. (2003). The evolution of tribospheny and the antiquity of mammalian clades. Molecular Phylogenetics and Evolution 28:360385.

Yapa, A. and Ratnavira, G. (2013). The Mammals of Sri Lanka. Field Ornithology Group of Sri Lanka, Karunaratne and Sons (Pvt.) Ltd., Colombo, Sri Lanka, pp. 1009.

Yoder, AD. (1997). Back to the future: a synthesis of Strepsirrhine systematics. Evolutionary Anthropology 6:11-21. 
Appendix 1. List of naturally occurring land-living mammals of Sri Lanka, excluding introduced taxa $†$. Definitions of climatic zones follow Eisenberg and McKay (1970). Taxon nomenclature and distributions by climate zone follow cited references (additional .references are found in those cited here). Asterisks denote $* * *$ endemic genus, $* *$ endemic species, and *endemic subspecies

[Colour photographs of many mammals are found in popular guides (de Silva Wijeyeratne 2008; Pethiyagoda, 2012; Pethiyagoda et al., 2012; Yapa and Ratnavira, 2013)]

\begin{tabular}{|c|c|c|}
\hline Native land-living mammal of Sri Lanka & $\begin{array}{l}\text { Distribution by } \\
\text { Climatic Zone }\end{array}$ & Reference \\
\hline \multicolumn{3}{|l|}{ Order Insectivora } \\
\hline \multicolumn{3}{|l|}{ FAMILY SORICIDAE (Shrews) } \\
\hline $\begin{array}{l}\text { Suncus murinus murinus (Linnaeus, 1766) } \\
\text { Common Indian Musk Shrew }\end{array}$ & $\mathrm{A}, \mathrm{B}, \mathrm{C}, \mathrm{D} 1$ & $1,2,3,4$ \\
\hline $\begin{array}{l}* * \text { Suncus montanus (Kelaart, 1850) } \\
\text { Highland Shrew }\end{array}$ & D3 & 1,4 \\
\hline $\begin{array}{l}\text { *Suncus murinus kandianus (Kelaart, 1853) } \\
\text { Kandyan Shrew }\end{array}$ & $\mathrm{D} 2$ & $1,2,4$ \\
\hline $\begin{array}{l}\text { **Suncus zeylanicus (Phillips, 1928) } \\
\text { Sri Lanka Jungle Shrew }\end{array}$ & $\mathrm{D} 2$ & $1,3,4$ \\
\hline $\begin{array}{l}\text { **Suncus fellowesgordoni Phillips, } 1932 \\
\text { Ceylon Pigmy Shrew }\end{array}$ & D3 & 1,4 \\
\hline $\begin{array}{l}\text { Suncus etruscus (Savi, 1822) } \\
\text { Pigmy Shrew }\end{array}$ & $\mathrm{D} 1, \mathrm{D} 2, \mathrm{D} 3$ & 4,5 \\
\hline $\begin{array}{l}\text { *Crocidura horsfieldi horsfieldi (Tomes, 1856) } \\
\text { Horsfield's Shrew }\end{array}$ & D2,D3 & $1,2,3,6$ \\
\hline $\begin{array}{l}* * \text { Crocidura miya Phillips, } 1929 \\
\text { Sri Lanka Long-tailed Shrew }\end{array}$ & D2,D3 & $1,2,3,6,7$ \\
\hline ** Crocidura hikmiya Meegaskumbura et al. , 2007 & $\mathrm{D} 1, \mathrm{D} 2$ & 6 \\
\hline $\begin{array}{l}\text { ***Solisorex pearsoni Thomas, } 1924 \\
\text { Person's Long-clawed Shrew }\end{array}$ & D2,D3 & $1,2,3,7$ \\
\hline $\begin{array}{l}\text { ***Feroculus feroculus (Kelaart, 1850) } \\
\text { Kelaart's Long-tailed Shrew }\end{array}$ & D3 & $1,2,5,24$ \\
\hline \multicolumn{3}{|l|}{ Order Chiroptera } \\
\hline \multicolumn{3}{|l|}{ FAMILY PTEROPIDAE (Fruit Bats) } \\
\hline $\begin{array}{l}\text { Pteropus giganteus giganteus (Brunnich, 1782) } \\
\text { Flying-fox }\end{array}$ & A to $\mathrm{D} 2$ & 1,2 \\
\hline $\begin{array}{l}\text { Cynopterus sphinx sphinx (Vahl, 1797) } \\
\text { Indian Short-nosed Fruit Bat }\end{array}$ & all zones & $1,2,3,5$ \\
\hline $\begin{array}{l}\text { *Cynopterus brachyotis ceylonensis (Muller, 1838) } \\
\text { Sri Lanka Short-nosed Fruit-bat }\end{array}$ & all zones & $1,2,3,8$ \\
\hline $\begin{array}{l}\text { Rousettus leschenaulti (Desmarset, 1820) } \\
\text { Fulvus Frit-bat }\end{array}$ & $(\mathrm{A}, \mathrm{B}, \mathrm{C}), \mathrm{D} 1, \mathrm{D} 2$ & $1,2,3,5$ \\
\hline
\end{tabular}

FAMILY RHINOLOPHIDAE (Horseshoe bats)

*Rhinolophus beddomei sobrinus (Anderson, 1918)

$\begin{array}{lr}\text { A, B, D1 } & 1,2,5 \\ \text { all zones } & 1,2,5\end{array}$

Rhinolophus rouxi rouxi Temminck, 1835

all zones

$1,2,5$

Rufous Horse-shoe Bat

\section{FAMILY HIPPOSIDERIDAE (Leaf-nosed Bats)}

*Hipposideros lankadiva lankadiva Kelaart, 1850

A to D2 $\quad 1,2$

Great Sri Lanka Leaf-nosed Bat

Hipposideros speoris speoris (Schneider, 1800)

C, D1, D2 
Hipposideros galeritus brachyotus (Dobson, 1874)

Dekhan Leaf-nosed Bat

*Hipposideros bicolor ater (Templeton, 1848)

Sri Lanka Bi-coloured Leaf-nosed Bat

\section{FAMILY MAGADERMATIDAE (False Vampire}

\section{Bats)}

* Megaderma spasma ceylonese Anderson, 1918

Sri Lanka False Vampire Bat

Megaderma lyra lyra Geoffroy, 1810

Indian False Vampire Bat

\section{FAMILY VESPERTILLIONIDAE}

Falsistrellus affinis (Dobson, 1871)

Chocolate Bat

*Pipistrellus ceylonicus ceylonicus (Kelaart, 1853)

Kelaart's Pipistrel

Pipistrellus coromandra (Gray, 1838)

Indian Pipistrel

Pipistrellus tenuis mimus (Temminck, 1840)

Indian Pigmy Pipistrel

Hesperoptenus tickelli (Blyth, 1851)

Tickell's Bat

Scotophilus heathi heathi (Horsfield, 1831)

Greater Yellow Bat

Scotophilus kuhli wroughtoni Leach, 1821

Lesser Yellow Bat

Myotis hasselti (Temminck, 1840)

Brown Bat

*Murina cyclotis eileenae (Phillips, 1932)

Sri Lanka Tube-nosed Bat

Kerivoula picta (Pallas, 1767)

Painted Bat

* Kerivoula hardwickei malpasi (Phillips, 1932)

Malpas's Bat

Miniopterus schreibersi fuliginosus (Hodgson, 1935)

Long-winged Bat

\section{FAMILY EMBALLONURIDAE (Sheath-tailed Bats)}

Taphozous longimanus Hardwicke, 1825

Long-armed Sheath-tailed Bat

Taphozous melanopogon Temminck, 1841

Black-bearded Sheath-tailed Bat

Saccolaimus saccolaimus Temminck, 1838

Pouch-bearing Sheath-tailed Bat

\section{FAMILY MOLOSSIDAE (Free-tailed Bats)}

Tadarida aegyptiaca thomasi Wroughton, 1919 Indian Wrinkled-lipped Bat

*Chaerephon plicatus insularis (Phillips, 1935)

Sri Lanka Wrinkle-lipped Bat
C, D1, D2 $\quad 1,2$
A, B, D1
$1,2,3,8$

D3

$1,2,3,5,8$

C, D1, D2, D3 1,2

A, B, C $\quad 1,2$

D1 (B, C)

$1,2,5,8$

A, B, C, D1 $\quad 1,2$

C, D1 $\quad 1,2$

A, B, C, D1 $\quad 1,2,3,5,8$
A, B
$1,2,3,5,8$

D2, (D1)

1,2 ,

$\mathrm{B}, \mathrm{C}, \mathrm{D} 1, \mathrm{D} 2 \quad 1,2,8$

D2 (D1) $\quad 1,2$

B, C, D1 $\quad 1,2$
A, B, C, D1
$1,2,8$
B, D1
$1,2,8$

A, B, C, D1 $\quad 1,2,5,8$

D2, D3 $1,2,3,5$

D2 


\section{FAMILY LORISIDAE (Slender Loris) $\dagger \dagger$}

**Loris tardigradus tardigradus (Linnaeus, 1758)

Red Slender Loris

*Loris lydekkerianus (tardigradus) nycticeboides (Hill, D3 1942)

D3

$1,2,9,10,12,15,16$

Montane Slender Loris

*Loris lydekkerianus grandis (Hill and Phillips, 1932)

C, D1, D2

$1,2,9,10,13,14,15$

Gray Slender Loris

*Loris lydekkerianus nordicus (Hill, 1933)

A, B, C $\quad 1,2,9,10,13,14,15$

Northern Slender Loris

FAMILY CERCOPITHECIDAE (Macaques and Langurs)

**Semnopithecus vetulus vetulus (Erxleben, 1777)

Southern Purple-faced Langur

**Semnopithecus vetulus nestor (Bennett, 1833)

D1, D2

$1,2,9,15$

Western Purple-faced Langur

*Semnopithecus vetulus monticola (Kelaart, 1850)

D1

$1,2,9,15,16,17$

Bear Monkey

D3

$1,2,9,15$

*Semnopithecus vetulus philbricki (Phillips, 1927)

A, B, C $\quad 1,2,9,15$

Northern Purple-face Langur

*Semnopithecus priam thersites (Blyth, 1844)

$\mathrm{A}, \mathrm{B}, \mathrm{C} \quad 1,2,9,15,16,17$

Hanuman or Grey Langur

**Macaca sinica sinica (Linnaeus, 1771)

A, B, C $\quad 1,2,9,15,16$

Dry-zone macaque

*Macaca sinica aurifrons (Pocock, 1931)

D1, D2

$1,2,9,15,16$

Wet-zone Macaque

* Macaca sinica opisthomelas (Hill, 1942)

D3

$1,2,9,15,16,18$

Montane Macaque

\section{Order Philodota}

FAMILY MANIDAE (Pangolins)

Manis crassicaudata Gray, 1827

Pangolin

A, B, C, D1, D2 1,2

\section{Order Rodentia}

\section{FAMILY SCIURIDAE (Squirrels)}

* Petaurista philippinensis lanka (Wroughton, 1911)

D1, D2, D3

$1,2,5$

Large Sri Lanka Flying-Squirrel

*Petinomys fuscocapillus layardi (Kelaart, 1850)

D1, D2

1,2

Small Sri Lanka Flying-Squirrel

*Ratufa macroura macroura (Pennant, 1769)

D2, D3

1,2

Highland Sri Lanka Giant-Squirrel

*Ratufa macroura melanochra Thomas and

D1

1,2

Wroughton, 1915

Black and Yellow Giant Squirrel

Ratufa macroura dandolena Thomas and Wroughton,

A, B, C

1,2

1915

Common Sri Lanka Giant Squirrel

*Funambulus palmarum brodiei (Blyth, 1849)

A

Northern Sri Lanka Palm Squirrel 
*Funambulus palmarum kelaarti (Layard, 1851)

Southern Sri Lanka Palm Squirrel

*Funambulus palmarum olympius Thomas and

Wroughton, 1915

Highland Sri Lanka Palm Squirrel

**Funambulus layardi (Blyth, 1849)

Flame-striped Jungle Squirrel

**Funambulus obscurus (Pelzen and Kohl, 1886)

Ceylon Dusky-striped Palm Squirrel

\section{FAMILY HYSTRICIDAE (Porcupine)}

Hystrix indica (Kerr, 1792)

Porcupine

\section{FAMILY MURIDAE (Rats and Mice)}

*Tatera indica ceylonica (Wroughton, 1906)

Sri Lanka Gerbil

Bandicota indica malabarica Hill, 1939

Greater Bandicoot Rat

* Bandicota bengalensis gracilis (Nehring, 1902)

Lesser Bandicoot Rat

Mus musculus urbanus (Hodgson, 1845)

House Mouse

*Mus booduga (cervicolor) fulvidiventris (Blyth, 1852)

Sri Lanka Field Mouse

**Mus fernandoni (Phillips, 1932)

Sri Lanka Spiny Mouse

**Mus mayori mayori (Thomas, 1915)

Highland Spiny Rat

*Mus mayori pococki Ellerman, 1947

Bi-coloured Spiny Rat

*Rattus rattus kandianus (Kelaart, 1850)

Common Sri Lanka House Rat

* Rattus rattus kelaarti (Wroughton, 1915)

Sri Lanka Highland Rat

Madromys blanfordi (Thomas, 1881)

White-tailed Rat

***Srilankamys ohiensis (Phillips, 1929)

Sri Lanka Bi-coloured Rat

**Rattus montanus Phillips, 1932

Nelu Rat

Golunda ellioti ellioti Gray 1837

Indian Bush Rat

* Golunda ellioti nuwara (Kelaart, 1850)

Sri Lanka Highland Bush Rat or "Coffee Rat"

Millardia meltada meltada (Gray, 1837)

Soft-furred Field Rat

Vandeleuria oleracea rubida (Thomas, 1914)

Long-tailed Tree Mouse

**Vandeleuria nolthenii Phillips, 1929

Sri Lanka Long-tailed Tree Mouse
A, B, C
1,2
D2, D3
1,2
B, C, D1, D2, D3 $19,1,2$
D1, D2, D3

all zones

1,2

$\begin{array}{ll}\text { (A, B,C, (D1 } & 1,2 \\ \text { B, C, D1, D2 } & , 2 \\ \text { A, B, C, D1, D2 } & 1,2 \\ \text { all zones } & 1,2\end{array}$

A, B, C, D $\quad 1,2,5$

A, B, C $\quad 1,2,3,8$

D2, D3 $\quad 1,2,7,8$

D1, D2 $\quad 1,2$

A, B, C, D1, D2 1,2

D2, D3

1,2

$\mathrm{A}, \mathrm{B}, \mathrm{C}$

D2, D3 $\quad 1,2,3,7,8$

D3

$1,2,3,7,8$

A, B, C, D $\quad 1,2$

D2, D3 $\quad 1,2$

A, B $\quad 1,2$

A, B, C, D1 $\quad 1,2,3$

D2, D3 $\quad 1,2,3,7,8$ 
Order Lagomorpha

FAMILY LEPORIDAE (Hares)

*Lepus nigricollis singhala Wroughton, 1915

all zones

1,2

Sri Lanka Black-naped Hare

\section{Order Carnivora \\ FAMILY MUSTELLIDAE (Otter)}

Lutra lutra nair (F. Cuvier, 1923)

all zones

1,2

Sri Lanka Otter

\section{FAMILY CANIDAE (Jackal)}

*Canis aureus lanka (Wroughton, 1916)

$\mathrm{A}, \mathrm{B}, \mathrm{C}, \mathrm{D} 1, \mathrm{D} 2 \quad 1,2$

Sri Lanka Jackal

\section{FAMILY URSIDAE (Bear)}

*Melursus ursinus inornatus (Pucheran, 1855)

A, B, C

Sri Lanka Sloth Bear

FAMILY VIVERRIDAE (Civets and Mongoose)

*Viverricula indica mayori Pocock, 1933

Sri Lanka Small Civet-cat

Paradoxurus hermaphroditus (Pallas, 1777)

Common Indian Palm Civet or Toddy Cat

**Paradoxurus aureus Cuvier, 1822

Wet-zone Golden Palm Civet

**Paradoxurus montanus Kelaart, 1853

C, D1, D2, D3

Sri Lanka Brown Palm Civet

**Paradoxurus stenocephalus Groves et al., 2009,

B, D2, D3

Dry-zone Golden Palm Civet

B

*Herpestes edwardsi lanka (Wroughton, 1915)

A, B, C

Grey Mongoose

*Herpestes fuscus flavidens (Kelaart, 1850)

D2, D3

Highland Sri Lanka Brown Mongoose

*Herpestes fuscus rubidior (Pocock, 1937)

D1

Western Sri Lanka Brown Mongoose

Herpestes fuscus maccarthiae (Gray, 1851)

A, B $\quad 1,2$

Northern Sri Lanka Brown Mongoose

*Herpestes smithi zeylanicus Thomas, 1921

Sri Lanka Ruddy Mongoose

Herpestes vitticollis Bennett, 1835

A, B, C, D1, D2 1,2

Striped-necked Mongoose

A, B, C, D2, D3 1,2

\section{FAMILY FELIDAE (Cats)}

*Prionailurus rubiginosus phillipsi Pocock, 1939

all zones

Sri Lanka Rusty-spotted Cat

Prionailurus viverrinus (Bennett, 1833)

A, B, C, D1 $\quad 1,2,5$

Indian Fishing Cat

Felis chaus affinis (Gray, 1830)
A, B
1,2

Sri Lanka Jungle Cat

* Panthera pardus kotiya (Meyer, 1794)

all zones

$1,2,21$

Sri Lanka leopard 


\section{Order Proboscidea \\ FAMILY ELEPHANTIDAE (Elephant)}

*Elephas maximus maximus Linnaeus, 1758

all zones

$1,2,22$

Elephant

\section{Order Artiodactyla \\ FAMILY SUIDAE (Pig)}

Sus scrofa cristatus (Wagner, 1839)

Wild Boar

all zones $\quad 1,2$

\section{FAMILY TRAGULIDAE (Chevrotain)}

**Moschiola meminna Erexleben, 1777

A, B, C, D1, D2 $23,1,2$

Sri Lanka Chevrotain (or Mouse-deer)

**Moschiola kathygre Groves and Meijaard, $2004 \quad$ D3 $23,1,2$

Sri Lanka Pigmy Chevrotain (or Mouse-deer)

\section{FAMILY CERVIDAE (Deer)}

Muntiacus muntjak malabaricus Lydekker, 1915

A, B, C, D1, D2 1,2

Barking Deer

*Axis axis ceylonensis Fischer, 1829

$\mathrm{A}, \mathrm{B}, \mathrm{C} \quad 1,2$

Spotted Deer

* Rusa unicolor unicolor Kerr, 1792

all zones

$8,1,2$

Sambur

1 Phillips (1980), 2 Eisenberg and McKay (1970), 3 McKay (1984), 4 Meegaskumbura and Schneider (2008), 5 Weerakoon and Goonatilake (2006), 6 Meegaskumbura et al. (2007), 7 Wijesinghe (2006), 8 Weekaroon (2012), 9 Molour et al. (2003), 10 Nekaris and Jayewardene (2004), 11 Gamage et al. (2009), 12 Gamage et al. (2010), 13 Perera (2008), 14 Perera et al. (2009), 15 Brandon-Jones et al. (2004), 16 Groves (2001), 17 Karanth (2010), 18 Hill (1942), 19 Dissanayake and Oshida (2012), 20 Groves et al. (2009), 21 Miththapala (2006), 22 Fernando et al. (2000), 23 Groves and Meijaard (2005), 24 Pethiyagoda (2012).

$\dagger$ Introduced forms normally cited in lists of Sri Lankan mammals include the following taxa: Rattus rattus rattus, $R$. $r$. alexandrinus, R.r. rufescens, Rattus norvegicus, Axis porcinus porcinus, Bubalus bubalis bubalis, Equus caballus.

†† Compilation excludes online proposed subspecies: Northwestern red slender loris (Loris tardigradus parvus) and Uva red slender loris (L. lydekkerianus uva) (Gamage et al., 2017). 